\title{
REVIEW
}

\section{Drug transporters, the blood-testis barrier, and spermatogenesis}

\author{
Linlin Su, Dolores D Mruk and C Yan Cheng \\ The Mary M Wohlford Laboratory for Male Contraceptive Research, Center for Biomedical Research, Population Council, 1230 York Avenue, New York, \\ New York 10065, USA \\ (Correspondence should be addressed to C Y Cheng; Email: y-cheng@popcbr.rockefeller.edu)
}

\begin{abstract}
The blood-testis barrier (BTB), which is created by adjacent Sertoli cells near the basement membrane, serves as a 'gatekeeper' to prohibit harmful substances from reaching developing germ cells, most notably postmeiotic spermatids. The BTB also divides the seminiferous epithelium into the basal and adluminal (apical) compartment so that postmeiotic spermatid development, namely spermiogenesis, can take place in a specialized microenvironment in the apical compartment behind the BTB. The BTB also contributes, at least in part, to the immune privilege status of the testis, so that anti-sperm antibodies are not developed against antigens that are expressed transiently during spermatogenesis. Recent studies have shown that numerous drug transporters are expressed by Sertoli cells. However, many of these same drug transporters are also expressed by spermatogonia, spermatocytes, round spermatids,
\end{abstract}

elongating spermatids, and elongated spermatids, suggesting that the developing germ cells are also able to selectively pump drugs 'in' and/or 'out' via influx or efflux pumps. We review herein the latest developments regarding the role of drug transporters in spermatogenesis. We also propose a model utilized by the testis to protect germ cell development from 'harmful' environmental toxicants and xenobiotics and/or from 'therapeutic' substances (e.g. anticancer drugs). We also discuss how drug transporters that are supposed to protect spermatogenesis can work against the testis in some instances. For example, when drugs (e.g. male contraceptives) that can perturb germ cell adhesion and/or maturation are actively pumped out of the testis or are prevented from entering the apical compartment, such as by efflux pumps.

Journal of Endocrinology (2011) 208, 207-223

\section{Introduction}

In the mammalian testis, as in rats, spermatogenesis is a complex cellular event that takes place in the seminiferous epithelium of seminiferous tubules. During spermatogenesis the spermatogonia (2n) undergo mitosis, followed by a cellular transformation from type B spermatogonia into spermatocytes, which enter meiosis to form spermatids (1n), and finally develop to spermatozoa via spermiogenesis. Hormonally, spermatogenesis is supported by two pituitary hormones, namely the FSH and LH. FSH exerts its effects on Sertoli cells, whereas LH regulates steroidogenesis in Leydig cells in the interstitium (Sharpe 1994, Cheng \& Mruk 2010b) which are involved in the production of testosterone and estrogens to regulate spermatogenesis (Shaha 2008, Carreau \& Hess 2010, Carreau et al. 2010). In short, spermatogenesis is composed of i) mitotic renewal of spermatogonial stem cells and spermatogonia, ii) transformation of type B spermatogonia to preleptotene spermatocytes, iii) transit of preleptotene spermatocytes across the blood-testis barrier (BTB), iv) meiosis, v) differentiation of round spermatids to spermatozoa via spermiogenesis, and vi) spermiation. The BTB anatomically divides the seminiferous epithelium into the basal and the apical compartment. As such, the entire event of postmeiotic germ cell development, namely spermiogenesis, and spermiation take place behind the BTB in the apical compartment. Spermatids differentiate into spermatozoa by undergoing a series of 19, 16 and 6 transformation steps in rats, mice and men, respectively, with profound morphological changes including the formation of the acrosome, condensation of genetic materials into the spermatid head, and the elongation of the tail (de Kretser \& Kerr 1988, Hess \& de Franca 2008, Cheng \& Mruk 2010b). Additionally, the BTB confers, at least in part, immune privilege status to the testis (Meinhardt \& Hedger 2010) in order to avoid the production of auto-antibodies against antigens on spermatocytes and spermatids, many of which are expressed transiently during spermatogenesis. We discuss herein the critical function of drug transporters (both efflux and influx pumps) in the testis and their role at the BTB in relation to spermatogenesis. 


\section{BTB structure and function}

The BTB is one of the tightest blood-tissue barriers known to exist in mammalian tissues. Unlike other blood-tissue barriers, such as the blood-brain and the blood-retina barriers which constitute almost exclusively tight junctions (TJs) between endothelial cells, the BTB - most notably in rodents, primates, and humans - is constituted of coexisting specialized junctions between Sertoli cells near the basement membrane, which include TJs, basal ectoplasmic specializations (basal ESs), gap junctions (GJs), and desmosome-like junctions (Wong \& Cheng 2005, Cheng \& Mruk 2009, 2010b, Li et al. 2009, Cheng et al. 2010; see Fig. 1 and Table 1). The endothelial TJs in microvessels found in the interstitium between seminiferous tubules in the testis, however, contribute relatively little barrier function of the BTB. Furthermore, basal ESs that coexist with TJs at the BTB are typified by the presence of actin filament bundles sandwiched between the plasma membrane of Sertoli cells and cisternae of endoplasmic reticulum (see Fig. 1), making BTB a unique blood-tissue barrier ultrastructure (for a review, see Cheng \& Mruk (2010b)). Additionally, the BTB anatomically segregates the seminiferous epithelium into basal and apical (or adluminal) compartments (see Fig. 1) so that postmeiotic spermatid development (i.e. spermiogenesis) and spermiation take place in a specialized microenvironment behind the BTB. In short, the BTB creates an immunological barrier, so that antigens, many of which appear transiently during spermiogenesis, are sequestered from the systemic circulation to avoid the production of anti-sperm antibodies. In fact, this ultrastructure determines in large part the nutrients, ions, electrolytes, as well as hormonal, paracrine, and autocrine factors having access to the developing spermatids in the apical compartment. This is known as the 'barrier' function of the BTB. Furthermore, the BTB confers cell polarity (Wong \& Cheng 2009, Cheng \& Mruk 2010b) resulting in the nuclei of Sertoli cells being located near the basement membrane.

As noted above, the BTB is constituted by coexisting TJs, basal ESs, GJs, and desmosome-like junctions. It was thought that the 'barrier' function imposed by the BTB restricted the flow of substances including drugs across this immunological barrier. However, recent studies have demonstrated that the BTB is a highly dynamic ultrastructure, undergoing extensive restructuring at stages VIII-IX of the epithelial cycle thereby facilitating the transit of preleptotene spermatocytes across the BTB (Cheng \& Mruk 2010b, Mruk \& Cheng 2010). In addition, there are numerous drug transporters (including efflux and influx pumps) in Sertoli cells, that are known to structurally associate with $\mathrm{TJ}$ protein complexes at the BTB (see Table 1). These transporters determine which drugs have access to the developing germ cells in the apical compartment behind the BTB (Fig. 1). Recent studies by dual-labeled immunofluorescence analysis have shown that P-glycoprotein (an efflux pump) is co-localized with several BTB constituent proteins, such as TJ-proteins (occludin, claudin11,JAM-A, and ZO-1) and basal ES-proteins (N-cadherin and $\beta$-catenin) (Su et al. 2009). Moreover, the putative interaction of these drug transporters with proteins at the BTB was confirmed by co-immunoprecipitation experiments that demonstrated the association between P-glycoprotein and several BTB integral membrane proteins. Interestingly, an increase in association between P-glycoprotein and some

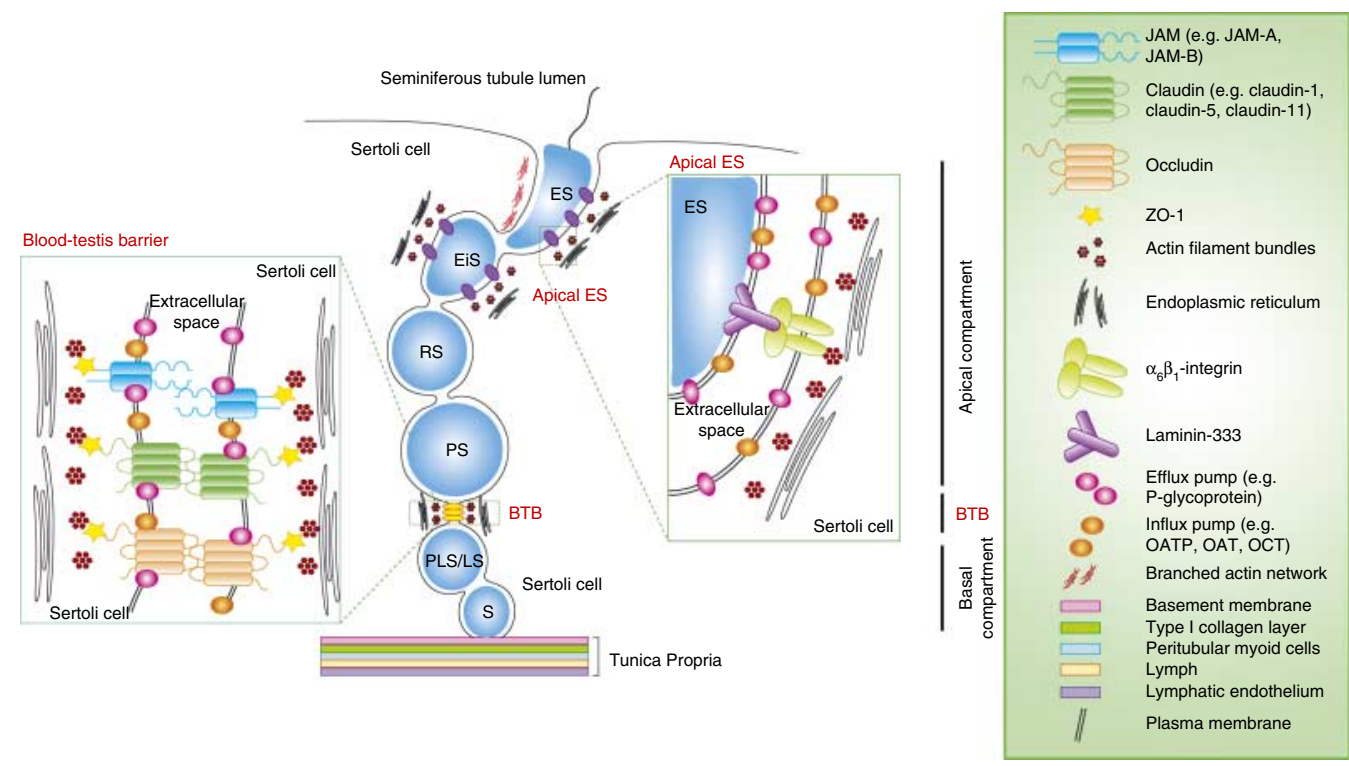

Figure 1 A schematic drawing illustrating the relative distribution of drug transporters, both influx and efflux pumps, in the seminiferous epithelium of adult rat testes. It is noted that both efflux pumps (e.g. P-glycoprotein) and influx pumps (e.g. OATP, OAT, and OCT) are found at the BTB and the apical ES, associated with the integral membrane proteins localized to either Sertoli cells at the BTB or Sertoli and elongating spermatids at the apical ES. Full colour version of this figure available via http://dx.doi.org/10.1677/JOE-10-0363. 
Table 1 Different junction types in the testis and the drug transporters found in these junctions

Junction types

Occluding junction

Tight junction

Anchoring junction

Adherens junction (actin-based),

such as apical ES

Desmosome-like junction (intermediate

filament based)

Communicating junction

Gap junction
Structural proteins

Occludins, claudins (e.g. claudin-1, $-5,-11)$, JAM-A, JAM-B, CAR, nectins, ZO-1

Cadherins, catenins, nectins, $\alpha_{6} \beta_{1}$-integrin, laminins, JAM-C, CAR, ZO-1, JAM-B, claudin-5, vinculin

Desmogleins, desmocollins, plakoglobin

Connexins (e.g. Cx43, Cx26)
Drug transporters found in Sertoli cells

P-glycoprotein, OCT1/SLC22A1, OCT3/SLC22A3, OCTN1/SLC22A4, OCTN2/SLC22A5 (Maeda et al. 2007), BCRP

P-glycoprotein (Su et al. 2009)

Not determined

Not determined
BTB proteins (e.g. occludin, claudin-11, and JAM-A) was detected after treatment with adjudin (Su et al. 2009) 1-(2,4dichlorobenzyl)-1H-indazole-3-carbohydrazide, a potential male contraceptive drug known to induce germ cell loss from the adult testis in rats, rabbits, and dogs (Cheng et al. 2005, Mruk et al. 2008, Hu et al. 2009, Cheng \& Mruk 2010c) suggesting that $\mathrm{P}$-glycoprotein forms a structural complex with occludin, claudin-11, and JAM-A at the BTB, which may take part in the process of regulating the drug concentration in the apical compartment of the seminiferous epithelium, similar to its 'gatekeeper' role at the blood-brain barrier (BBB; Schinkel 1999).

\section{Drug transporters in the testis}

Drug transporters are ubiquitously expressed in tissues and organs, such as the testis, kidney, liver, brain, and intestine, and they are crucial to drug absorption, disposition, metabolism, and excretion. The amount of drugs (e.g. adjudin), xenobiotics (e.g. cadmium, and bisphenol A), and other chemicals (e.g. mercury and lead) that enter different tissues and/or organs in mammals under physiological and pathological conditions are determined by drug transporters. About $60 \%$ of the $\sim 800$ drug transporters known to exist are integral membrane proteins that transport or prevent the transport of xenobiotics across biological membranes in cell epithelia and endothelia in mammals (Dallas et al. 2006, Rochat 2009, Franke et al. 2010, Kis et al. 2010). For instance, it is known that the entry of cadmium into the seminiferous epithelium behind the BTB requires the presence of ZIP8, a zinc transporter also known as SLC39A8 in mice (Dalton et al. 2005).

Drug transporters are classified either as primary active transporters that require ATP hydrolysis for function, or as secondary and tertiary active transporters driven by ion exchange or co-transport without the consumption of ATP. Owing to the growing number of drug transporters, the HUGO Gene Nomenclature Committee has classified all transporter proteins into two broad categories: i) ATP-binding cassette (ABC) and ii) solute carrier (SLC; see Tables 2 and 3). Both groups consist of many subfamily members that are involved in the transport of a broad range of drugs or substrates (see Table 2). Alternatively, drug transporters can be broadly classified as either influx or efflux pumps. These are defined solely by the direction in which they transport substrates or drugs. For instance, influx pumps (e.g. organic anion transporter (OAT)/organic aniontransporting polypeptide (OATP) and organic cation transporter $(\mathrm{OCT}) /$ organic cation transporting polypeptide (OCTP)) transport drugs into cells, whereas efflux pumps (e.g. P-glycoprotein, multidrug resistance protein-related proteins (MRPs), and breast cancer resistance protein (BCRP)) transport drugs out of cells and can also prevent the entry of 'unwanted' drugs into a cell (see Tables 2 and 3). Efflux pumps, thus, determine the amount of a drug inside a cell. The effect of efflux pumps are often realized in cancer patients who do not respond to chemotherapeutic drugs wherein tumor cells actively pump chemotherapeutic drugs out of the developing or metastatic tumor. The properties of drug transporters are important to consider in drug design because they play key roles in determining the bioavailability, pharmacokinetics, and efficacy of drugs. Furthermore, drugs can be designed to avoid certain tissues if these tissues lack specific influx transporters, thereby reducing adverse side effects and toxicity (Alam et al. 2010, Ganta et al. 2010, Gaucher et al. 2010, Kis et al. 2010). On the other hand, drugs may be developed or modified to target selected tissues that overexpress specific drug transporters following their exposure to certain drugs (Fardel \& Le Vee 2009, Yu et al. 2010). For the development of nonhormonal contraceptives for males, a better understanding of drug transporters in the testis is particularly important, since many compounds under investigation exert their effects behind the BTB, and have low bioavailability, due to the interactions between these drugs and drug transporters in the testis. We summarize below some of the latest findings in the field regarding drug transporters that are pertinent to our current investigation in developing novel compounds for male contraception. 

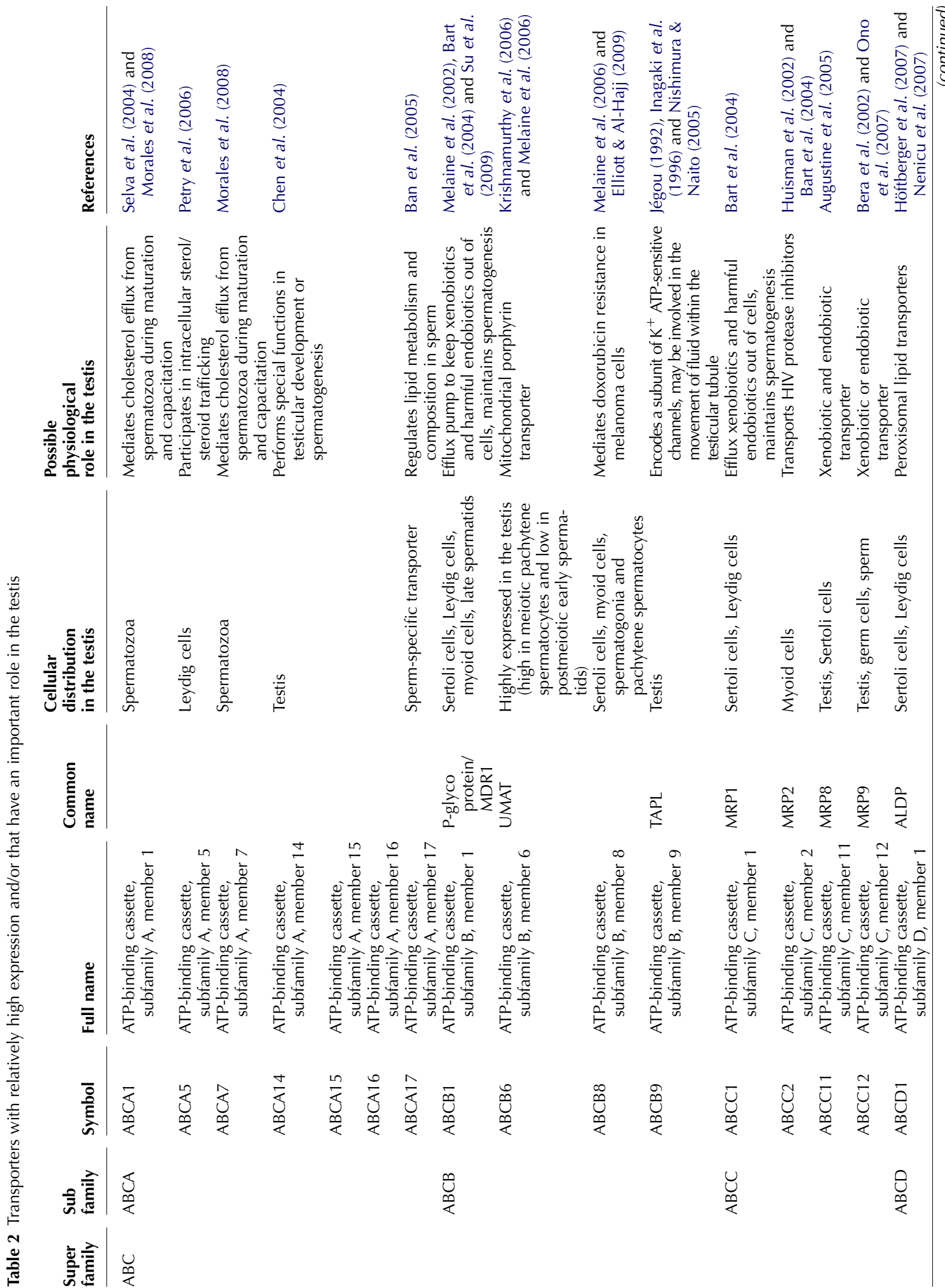

章|

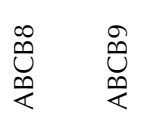

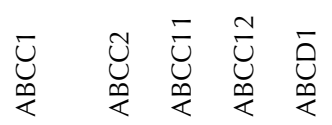

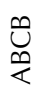

$\bigcup_{\longleftarrow}^{\cup}$

$\stackrel{0}{<}$ 


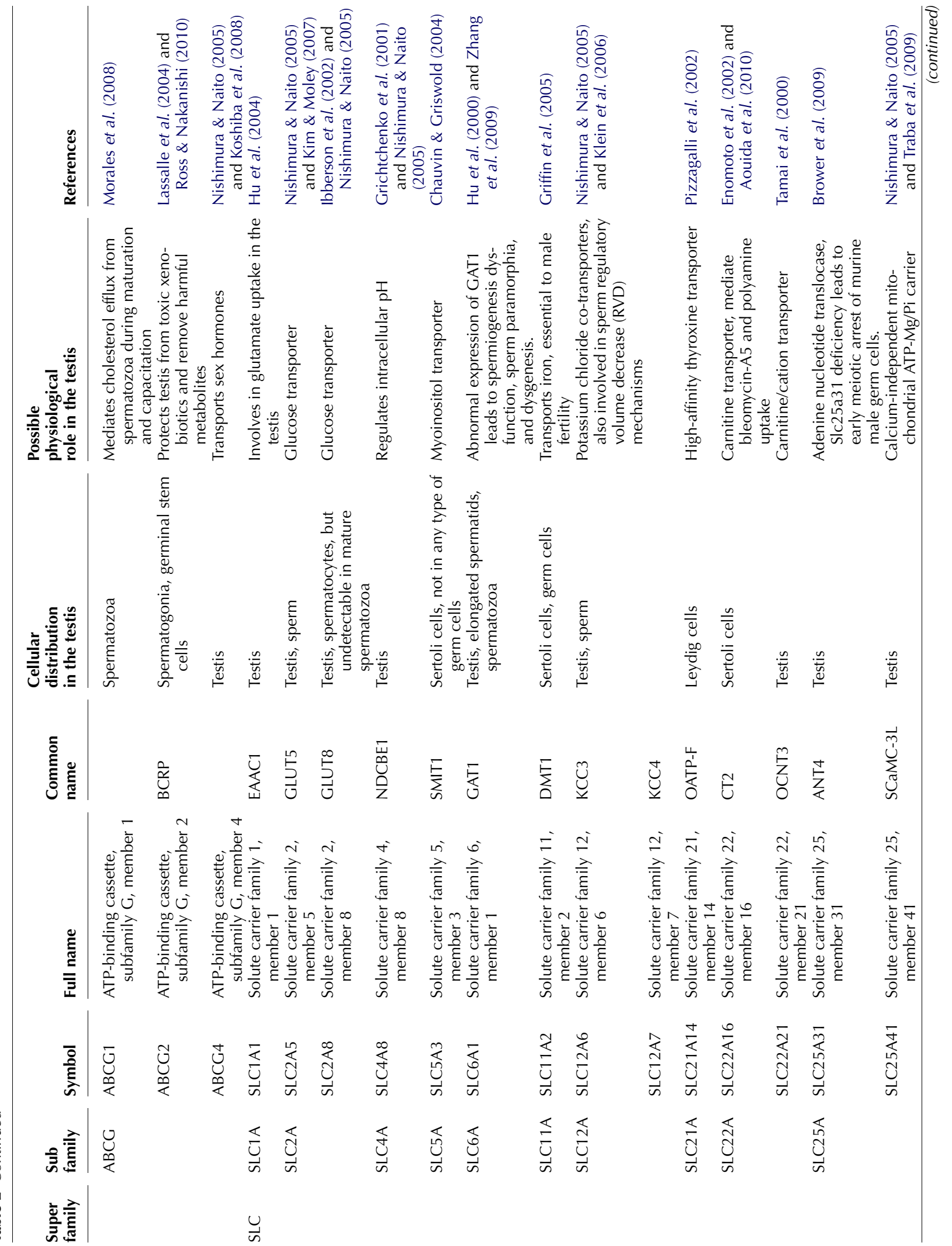




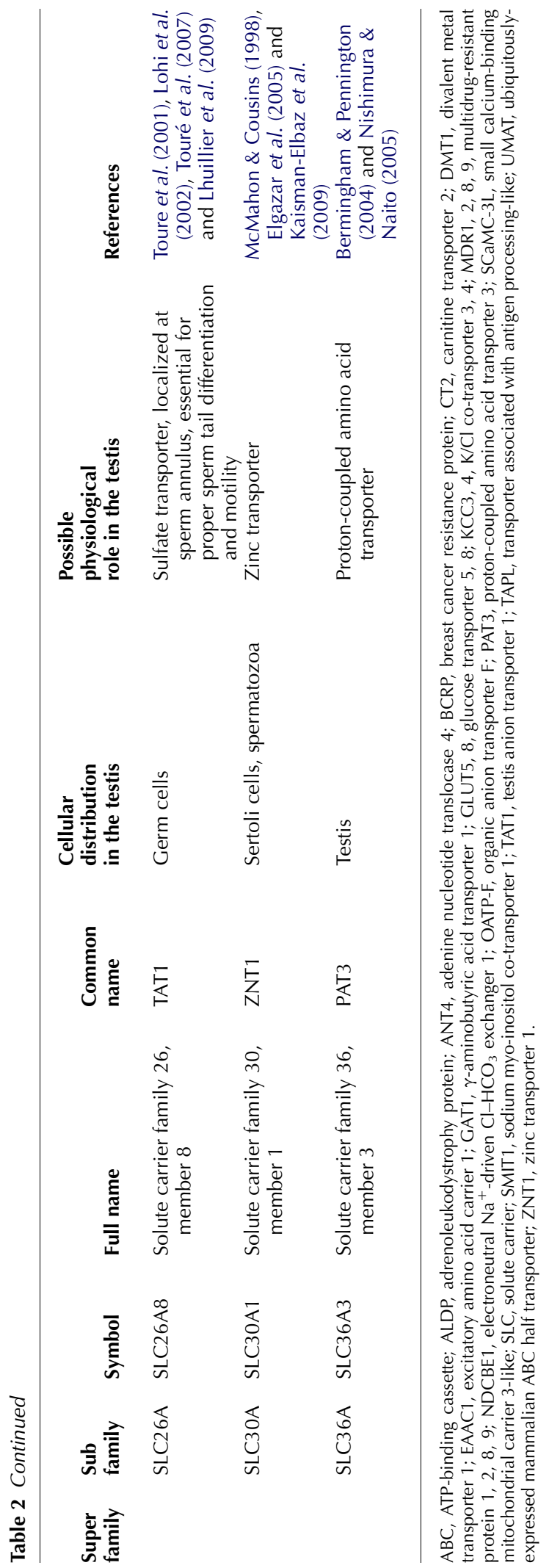

\section{$A B C$ transporter superfamily in the testis}

Virtually all $\mathrm{ABC}$ transporters in mammalian epithelial and/or endothelial cells are efflux pumps (see Tables 2 and 3). $\mathrm{ABC}$ transporters utilize a primary active transport (also known as a direct active transport) mechanism, which uses ATP directly as the energy source to actively transport drugs across the plasma membrane against a concentration gradient. Many ABC transporters are expressed at the $\mathrm{BTB}$ (Tables 2 and 3). There are three well-studied drug transporters in the $\mathrm{ABC}$ superfamily: i) multidrug resistance proteins (MDRs), ii) MDR-related proteins (MRPs), and iii) BCRP, which are discussed here (Tables 2 and 3). The $A B C$ genes are divided into seven subfamilies of $A B C 1, M D R /$ TAP (TAP, transporter, ABC, sub-family B), MRP, $A L D$ (not Abcd1), OABP (ABC, sub-family E), GCN20 (ABC, subfamily F), and WHITE (specifically for sterol or possibly for cholesterol transport; Dean et al. 2001, Fitzgerald et al. 2010, Green 2010, Shen \& Zhang 2010, Tomi \& Hosoya 2010).

\section{Multidrug resistance proteins}

The concept of multidrug resistance originated from studies in cancer biology (Dallas et al. 2006, Shukla et al. 2010). During chemotherapy, cancer cells develop resistance to anticancer drugs. Even though many of these drugs are structurally and functionally unrelated, cancer cells will gain the ability to actively pump these drugs out of the developing tumors and/or prevent the entry of these drugs to tumor cells. This phenomenon is known as multidrug resistance. Subsequent studies have shown that multidrug resistance is mediated by integral membrane proteins known as MDRs. MDRs are efflux pumps that actively pump chemotherapeutic drugs out of cancer cells, or simply prevent their entry into cells, and are also found in normal epithelial and endothelial cells in mammals (Rochat 2009, Ni et al. 2010, Shukla et al. 2010).

The best-studied MDR is the P-glycoprotein (Miller et al. 2008, Li et al. 2010, Miller 2010). There are three separate P-glycoprotein-encoding genes found in rodents, namely multidrug resistance 1 gene $M d r 1$ (or $M d r 1 b$ ), $M d r 2$, and $M d r 3$ (or Mdr1a). However, only Mdr1 and Mdr3 encode the MDR phenotype of P-glycoprotein (Couture et al. 2006, Miller et al. 2008, Setchell 2008, Crowley \& Callaghan 2009). Although $M d r 2$ shows a $85 \%$ amino acid homology with Mdr1 (Gros et al. 1988), Mdr2 transports hepatic phospholipids into bile, and is not an efflux pump (Smit et al. 1993). In the testis, Mdr3 is highly expressed (Croop et al. 1989), and is detected in Sertoli cells, Leydig cells, peritubular myoid cells, and late spermatids, but not in spermatogonia, spermatocytes, or early spermatids (Melaine et al. 2002, Bart et al. 2004). In humans, P-glycoprotein is the product of MDR1 (ABCB1) and MDR2 (ABCB4; van der Bliek et al. 1988), with MDR2 functioning as a phosphatidyl translocase in the liver instead of a drug transporter (Ruetz \& Gros 1994). 

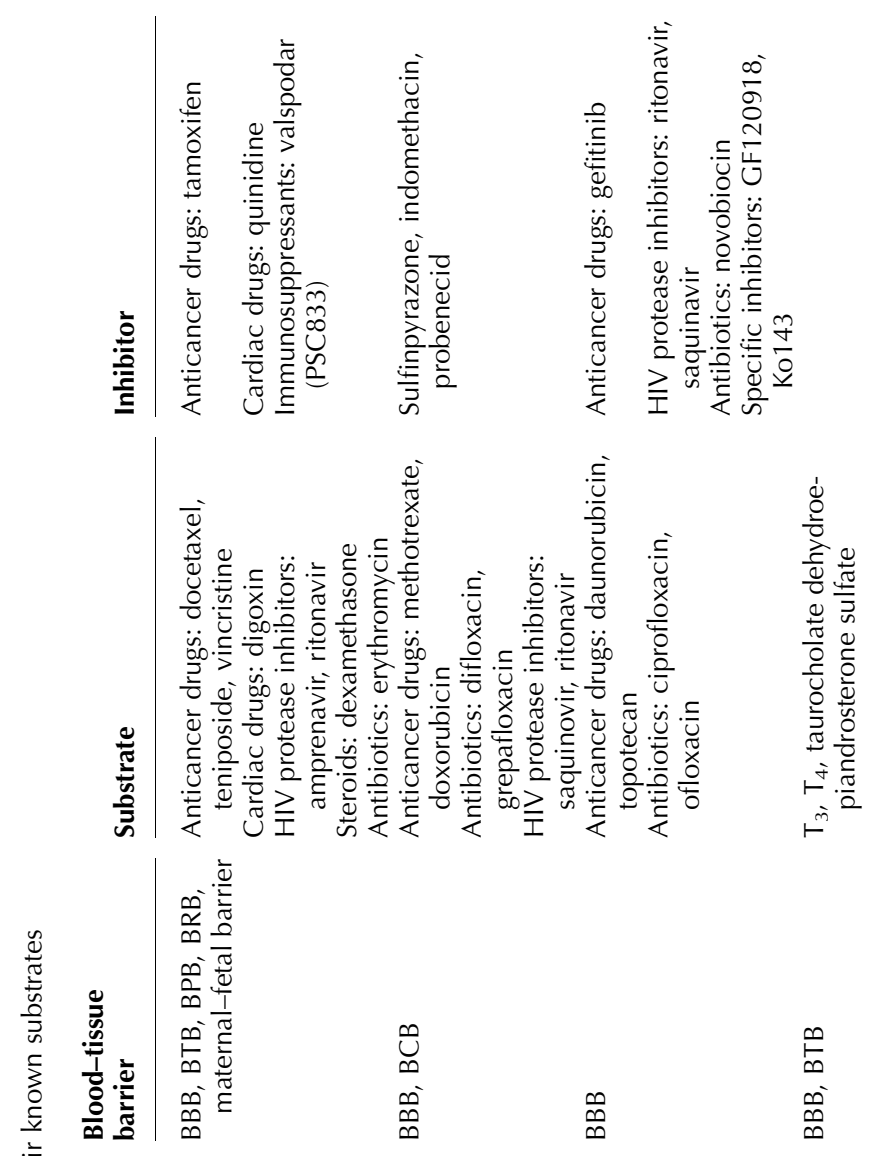

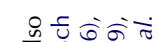

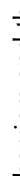

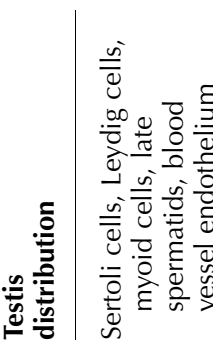

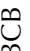

文

$\infty$

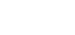

(

0 
P-glycoprotein was first discovered in cancer cells showing resistance to diverse classes of chemotherapy drugs whose structures did not share any similarities (Schinkel \& Jonker 2003, Fromm 2004, Leslie et al. 2005). In short, P-glycoprotein pumps therapeutic drugs out of tumor cells that recognize these drugs as 'harmful.' Subsequent studies have shown that $\mathrm{P}$-glycoprotein is also found in many normal tissues and cells, such as in small intestine (Muller et al. 2003), in endothelial cells that constitute the BBB (Miller et al. 2008, Miller 2010), and in Sertoli cells that create the BTB

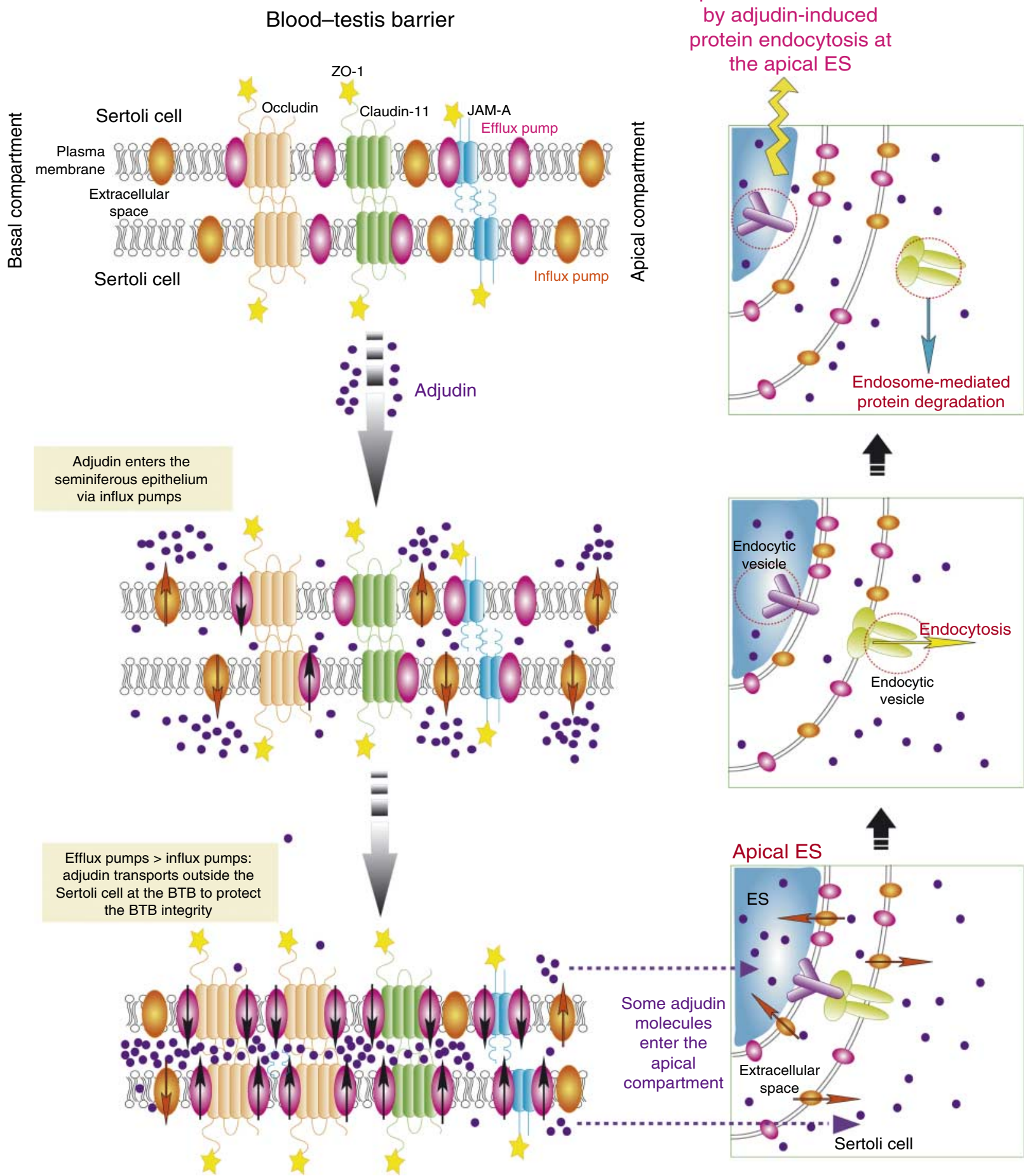


(Su et al. 2009). In the testis, P-glycoprotein is also found in late spermatids, but not spermatogonia, spermatocytes, or early spermatids (Melaine et al. 2002). This finding is somewhat in contrast to the result of Trezise et al. (1992) who reported that P-glycoprotein is detected in spermatogonia and endothelial cells in micro vessels in rat testes.

The substrates of P-glycoprotein include a wide variety of therapeutic drugs, such as anticancer drugs, antihypertensive agents, antidepressants, antibiotics, antimycotics, antiviral agents, immunosuppressants, and others (Marzolini et al. 2004, Dallas et al. 2006; Table 3). Some of these drugs also serve as inhibitors for P-glycoprotein (Marzolini et al. 2004). It is also possible that many drugs interact with $\mathrm{P}$-glycoprotein at different binding sites (Ford 1995).

In the testis, $\mathrm{P}$-glycoprotein is an integrated component of occludin-, claudin-11-, and JAM-A-based TJ-protein complexes, as well as of the $\mathrm{N}$-cadherin-based basal ES-protein complex at the BTB (Su et al. 2009). Accordingly, studies by immunohistochemistry and dual-labeled immunofluorescence analysis have shown that $\mathrm{P}$-glycoprotein is expressed abundantly in the seminiferous epithelium near the basement membrane and it co-localizes with occludin, claudin-11, JAM-A, and N-cadherin ( $\mathrm{Su}$ et al. 2009). However, P-glycoprotein staining was also detected at the apical ES at the Sertoli cell-spermatid interface (Su et al. 2009). It also appears that the localization of P-glycoprotein at the BTB in the seminiferous epithelium is not stage specific since a relatively high level of expression was detected during the entire seminiferous epithelial cycle (Su et al. 2009). More importantly, the BTB integral membrane proteins were found to structurally interact with P-glycoprotein as demonstrated by co-immunoprecipitation experiments. Furthermore, P-glycoprotein became more tightly associated with occludin, claudin-11, and JAM-A following exposure of rats to adjudin (Su et al. 2009), an agent that is known to induce germ cell, in particular spermatid, depletion from the seminiferous epithelium (for a review, see Mruk et al. (2008)). These findings support a notion that, with the other BTB proteins, the P-glycoprotein acts as a 'gatekeeper' for adjudin entrance (see Fig. 2), a drug harmful for germ cell adhesion in the apical compartment, out of the seminiferous epithelium actively or to prevent the entry of adjudin into the apical compartment. These findings are in agreement with the extremely low bioavailability of adjudin, a potential male contraceptive being actively pursued in our laboratory (Mruk et al. 2008, Cheng \& Mruk 2010c), making it somewhat difficult to deliver this and other related drugs to the apical compartment so that they can induce premature release of germ cells, without perturbing the hypothalamic-pituitarytesticular axis.

\section{Multidrug resistance-related proteins}

MRP is another efflux transporter subfamily of the ABC transporters, which is distantly related to P-glycoprotein. There are three members of the MRP family showing drugtransporting capability. They are MRP1 (ABCC1), MRP2 (ABCC2), and MRP3 (ABCC3), which were initially found in human tumor cells (see Table 3). Members of the MRP subfamily appear to have overlapping substrate specificities, but differ in their kinetic properties (Keppler et al. 1999). MRP1 is ubiquitously present in many tissues, including rodent testes, where it is mostly expressed in the basal compartment of the Sertoli cells (Wijnholds et al. 1998, Bart et al. 2004) and in Leydig cells (Bart et al. 2004). MRP2 and MRP3 are found mostly in liver and kidney but MRP2 is absent in the brain (Keppler et al. 1999). All the MRP proteins are localized to the basolateral membrane of polarized epithelial cells (Flens et al. 1996, Schaub et al. 1997, König et al. 1999, Kool et al. 1999).

MRP1 is a glycosylated and phosphorylated transmembrane protein with an apparent $M_{\mathrm{r}}$ of $190 \mathrm{kDa}$. While MRP1 is an efflux drug transporter, it shares only $15 \%$ amino acid homology with P-glycoprotein. However, the partial overlap in substrate specificity indicates that MRP1 and P-glycoprotein are functionally similar. Besides anticancer drugs and antibiotics, MRP1 also transports many naturally occurring compounds, such as GSH, GSH disulfide, glucuronide, and several sulfate conjugates out of cells (Lautier et al. 1996, Loe et al. 1996). Furthermore, MRP1

Figure 2 A schematic drawing illustrating the role of drug transporters in regulating the amount of drugs (e.g. adjudin) that can gain entry to the adluminal (apical) compartment in the seminiferous epithelium. The upper left panel shows the molecular architecture of some of the known integral membrane proteins at the BTB, such as occludin, claudins (e.g. claudin-1, claudin-5, and claudin-11), JAMs (e.g. JAM-A and JAM-B), and the association of efflux pumps (e.g. P-glycoprotein) and/or influx pumps (e.g. OATP, OAT, and OCT) with some of these integral membrane proteins (Cheng \& Mruk 2010b, Morrow et al. 2010, Mruk \& Cheng 2010). When the animals or humans are exposed to toxicants and/or drugs, such as adjudin, these compounds enter the seminiferous epithelium via influx pumps (e.g. OATP drug transporters; see middle left panel). It was reported that when rats were exposed to adjudin (a single dose at $50 \mathrm{mg} / \mathrm{kg}$ b.w. via gavage), a surge in P-glycoprotein steady-state protein level by as much as fourfold was detected within $6-12 \mathrm{~h}$ following drug treatment, which was accompanied by a sixfold increase in the association between P-glycoprotein and the occludin-ZO-1 protein complex within 9-12 $\mathrm{h}$ after drug treatment, so that 'unwanted' harmful adjudin could be pumped outside cells (both Sertoli and developing germ cells) or prevented from entering cells in the seminiferous epithelium (see lower left panel). This thus provides a unique mechanism to protect the testes from unwanted harmful substances reaching the developing spermatids in the apical compartment behind the BTB. However, some adjudin molecules may still enter the BTB, perhaps via the influx pumps (or via diffusion) and can have access to the apical ES in developing spermatids (see lower right panel). Adjudin likely exerts its effects by enhancing protein endocytosis (see middle right panel) and subsequent endosome-mediated protein degradation (see upper right panel), thereby destabilizing the apical ES. This, in turn, leads to germ cell (e.g. elongating spermatids) loss from the seminiferous epithelium. Full colour version of this figure available via http://dx.doi.org/10.1677/JOE-10-0363. 
can transport metals from the cells across the plasma membrane, including sodium arsenate and antimony potassium tartrate (Lorico et al. 2002). This function illustrates its protective role against environmental metal-based toxicants.

Similar to P-glycoprotein knockout mice, $M r p^{(-/-)}$ mice did not display embryonic death nor any changes in fertility as compared to wild-type mice (Rappa et al. 1999). However, etoposide-phosphate (ETOPOPHOS)-treated (an antineoplastic agent) $M r p^{(-/-)}$mice had a significant reduction in testis weight, as well as a severe disruption in spermatogenesis: the mice were devoid of meiotic division, displayed the presence of round spermatids in the tubule lumen, and presented with very few spermatozoa in the epididymis as compared with drug-treated wild-type mice (Wijnholds et al. 1998). It should be noted that the ETOPOPHOS-treated wild mice also showed a disruption in spermatogenesis, but meiotic divisions still occurred, and the epididymis contained many normal spermatozoa, plus some prematurely released round spermatids. Taking these data collectively, Mrp1 appears to possess a protective role in maintaining BTB function, and its deletion impedes spermatogenesis via a loss of BTB function. However, the BTB integrity in these mice remains to be investigated.

\section{Breast cancer resistance protein}

BCRP (also known as ABCG2) is expressed in the testis (Bart et al. 2004), being detected in endothelial cells of microvessels and peritubular myoid cells (Bart et al. 2004). BCRP, an efflux pump, is known to limit the penetration of phytoestrogens, such as daidzein, genistein, and coumestrol into the testis as shown in $B \mathrm{crp}{ }^{-/-}$mice (Enokizono et al. 2007), indicating its protective role against the adverse effects of phytoestrogens on spermatogenesis (Delclos et al. 2001, Wisniewski et al. 2003, Kyselova et al. 2004). BCRP, similarly to that shown for P-glycoprotein, also limits the penetration of common basic or neutral compounds, such as 2-amino-1-methyl-6phenylimidazol[4,5-b]pyridine (PhIP), 2-amino-3,8dimethylimidazol[4,5-f]quinoxaline (MeIQx), prazosin, and triamterene into the brain (Delclos et al. 2001, Wisniewski et al. 2003, Kyselova et al. 2004). However, most BCRP-specific substrates are weak acids (Enokizono et al. 2008). The action of BCRP, thus, complements the activity of P-glycoprotein in excluding acidic xenobiotic compounds from the brain or the testis, illustrating the in vivo significance of BCRP in conferring drug resistance. Another BCRP structurally related protein encoded by the cystic fibrosis gene is also expressed in spermatids but not in endothelial cells (Trezise \& Buchwald 1991, Trezise et al. 1992). Until now, there have been no studies carried out regarding this class of efflux pumps in testicular function, in particular their role in spermatogenesis and BTB dynamics.

\section{Solute carrier (SLC) transporter superfamily in the testis}

The SLC transporter superfamily is comprised of several subfamilies: OATs, OATPs, OCTs, organic cation/carnitine transporters (OCTNs), as well as peptide transporters, concentrative nucleoside transporters, equilibrative nucleoside transporters, and others. Many of the SLC transporters are efflux pumps, but OATPs, OATs, OCTs, and OCTNs are influx pumps (see Table 2). The SLC transporters typically use a secondary and tertiary active transport mechanism to transport drugs into a cell, this is different from $\mathrm{ABC}$ transporters that utilize primary active transport, which directly uses energy (i.e. ATP) to transport drugs across the plasma membrane. In essence, SLC transporters do not use ATP directly, and the energy is derived from a gradient that is created by a primary active transport system, such as the electrochemical potential difference created by pumping ions out of a cell. Alternatively, drugs (e.g. small ionic compounds) or environmental toxicants (e.g. heavy metals) can be transported across 'pores' present in SLC transporters, such as OATs or OATPs. SLC transporters play a crucial role in the influx and/or efflux of many organic anionic and cationic compounds in epithelial and endothelial cells. Among the 43 SLC subfamilies, the SLC21/SLCO (OATP) and SLC22 subfamilies (OAT/OCT/OCTN) are two of the best-studied ion transporters (Kalliokoski \& Niemi 2009, Fahrmayr et al. 2010, Kis et al. 2010, Klaassen \& Aleksunes 2010). We briefly summarize herein a few selected ion transporters relevant to spermatogenesis.

\section{SLC21/SLCO (OATP) subfamily}

The SLC21/SLCO subfamily of SLC superfamily is also known as OATP subfamily, with 15 and 10 isoforms of OATP identified in rodents and humans respectively (Kalliokoski \& Niemi 2009, Fahrmayr et al. 2010). OATPs are influx pumps responsible for the entry of drugs into cells. However, some OATP members can function as both influx and efflux pumps. For instance, Oatp2 mediates bidirectional transport of organic anions ( $\mathrm{Li}$ et al. 2000). OATPs mediate transport of a wide spectrum of amphipathic organic anions, and each OATP protein has a predicted membrane topology that comprises $12 \alpha$-helical transmembrane domains with amino and carboxyl termini embedded within the membrane (Mikkaichi et al. 2004).

OATPs are found in the liver, kidney, lungs, intestine, and testes (see Table 2). In the testis, OATP-F (Slc21a14) is limited to Leydig cells (Pizzagalli et al. 2002), and it mediates the disposition of thyroid hormones in the testis. OATP6B1 (Slco6b1, Tst1) and OATP6C1 (Slco6c1, Tst2) are specifically expressed in the testis, limited to Sertoli cells, spermatogonia, and Leydig cells (Suzuki et al. 2003), and OATP3 (Slc21a7) mRNA is highly expressed in Sertoli cells (Augustine et al. 2005). 
The substrates of OATPs include therapeutic drugs (e.g. statins and cardiac glycosides) and endogenous biomolecules (e.g. thyroxine, steroid conjugates, taurocholate, and bile acids). Substrates transported into the bile by hepatic OATPs are usually structurally large chemicals and low extracellular $\mathrm{pH}$ was found to enhance OATP transport activity (Leuthold et al. 2009).

OATP3 (Slc21a7) was first isolated from rat retina, it has 670 amino acid residues, and shows 80 and $82 \%$ identity with OATP1 and OATP2 respectively (Abe et al. 1998). Oatp3 mRNA has been shown to be highly expressed in the testis (e.g. Sertoli cells), as well as in the liver, kidney, retina, and brain (Abe et al. 1998, Ohtsuki et al. 2004, Augustine et al. 2005). The function of OATP3 is not fully known but it is involved in thyroid hormone and taurocholate transport (Abe et al. 1998). In the brain, studies by immunohistochemistry have shown that OATP3 is localized at the brush-border membrane of mouse choroid plexus epithelial cells, in neural cells, and the olfactory bulb, as well as in brain capillary endothelial cells (Ohtsuki et al. 2004). In the testis, OATP3 is detected at the BTB with highest expression from stages VII to $\mathrm{X}$ of the seminiferous epithelial cycle ( $\mathrm{Su} \&$ Cheng, unpublished data).

\section{SLC22 subfamily}

This family contains three classes of transporters: OATs, OCTs, and OCTNs (see Table 2). The OAT class has four members: OAT1, OAT2, OAT3, and OAT4, corresponding to $S L C 22 A 6,7,8$, and 11 , which can act as efflux or influx pumps, depending on their localization and energy requirement (Pritchard \& Miller 1993, Sekine et al. 2000). Sodium-dependent OATs, localized at the basolateral membrane of proximal tubular cells in kidney, are crucial to the reabsorption of anionic substances; while sodiumindependent and ATP-required active OATs, which are localized on the luminal site, are primarily involved in the secretion of organic anions (Pritchard \& Miller 1993, Sekine et al. 2000).

OCTs are polyspecific cationic transporters and they include OCT1-3 (SLC22A1-3). There are three OCTN members in humans: OCTN1 (SLC22A4), OCTN2 (SLC22A5), and CT2 (SLC22A16), which are responsible for carnitine and/or cation influx (Tamai et al. 2000, 2001, Enomoto et al. 2002). In rodents, another carnitine transporter-OCTN3 has also been cloned (Tamai et al. 2000). OCTs and OCTNs have broad tissue distribution and are found in the liver, kidney, and small intestine. OCT1, OCT3, OCTN1, and OCTN2 are expressed by Sertoli cells in the testis (Klaassen \& Aleksunes 2010). However, OCT2 is not detected in the rodent testis or Sertoli cells (Koepsell et al. 2007). OCT3 in rodents and OCT2 in humans are primarily expressed in the testis (Koepsell et al. 2007). OCT1 and OCTN2 are found at the basolateral membrane of Sertoli cells (Kobayashi et al. 2005, Maeda et al. 2007), while OCT3 is detected on the apical site of Sertoli cells (Maeda et al. 2007).

OCTs transport a wide range of structurally different, positively charged molecules, which usually have low $M_{\mathrm{r}}$ of $<500 \mathrm{Da}$ (Schmitt \& Koepsell 2005). Both the substrates and inhibitors of OCT1-3 are broadly overlapping. Oct $1^{(-/-)}$, $\mathrm{Oct} 2^{(-/-)}, \mathrm{Oct} 3^{(-/-)}$, and $\mathrm{Oct} 1^{(-/-)} / \mathrm{Oct} 2^{(-/-)}$(double knockout) mice have been generated (Jonker et al. 2001, 2003, Zwart et al. 2001, Jonker \& Schinkel 2004). Although these Oct knockout mice were fertile without any obvious defects, the transport of certain substrates and the tissue distribution of these substrates in the liver, kidney, heart, and small intestine were altered.

OCTN2 and OCTN3 are the two L-carnitine transporters, which are highly expressed in the testis (Kobayashi et al. 2007). L-carnitine is an essential factor for sperm maturation and metabolism during the transit of spermatozoa in the epididymis where they acquire motility (Jeulin \& Lewin 1996). Studies by immunohistochemistry have shown that OCTN2 and OCTN3 are localized to the distal and proximal portion of sperm tail respectively (Kobayashi et al. 2007), and both of these influx pumps mediate the supply of carnitine and acetylcarnitine to epididymal spermatozoa in mice (Kobayashi et al. 2007). Mutations in the gene encoding OCTN2 have been shown to cause obstructive azoospermia in the epididymis (Yakushiji et al. 2006), illustrating the significance of OCTN influx pumps in fertility.

\section{The role of drug transporters in BTB dynamics and spermatogenesis}

As summarized in the above sections, drug transporters, both efflux and influx pumps, are not limited to Sertoli cells that constitute the BTB in the mammalian testis even though Sertoli cells express many of these drug transporters. Instead, different classes of germ cells express high levels of different drug transporters at different stages of the seminiferous epithelial cycle of spermatogenesis (Table 2). These findings seemingly suggest that nature has installed a unique mechanism in the testis to ensure the integrity of spermatogenesis. Besides the $\mathrm{BTB}$ in the seminiferous epithelium to segregate the events of postmeiotic germ cell development from the systemic circulation, developing spermatids have the ability to pump harmful substances outside these cells and to selectively uptake substances necessary for their development. Furthermore, germ cells (e.g. preleptotene spermatocytes, undifferentiated and differentiated spermatogonial stem cells) that lie outside the BTB also express many drug transporters (Table 2). Recent studies have also demonstrated the unique role of drug transporters in spermatogenesis, as depicted in Fig. 2. It is known that the BTB is constituted by different $\mathrm{TJ}$ integral membrane proteins: occludin, claudins (e.g. claudin- $1,-5$, and -11), and JAMs (e.g. JAM-A and JAM-B; Fig. 2; Cheng \& Mruk 2010b, Morrow et al. 2010, Mruk \& Cheng 2010). 
Interestingly, P-glycoprotein was shown to associate with some of the integral membranes proteins at the BTB including occludin, claudin-11, and JAM-A (Su et al. 2009). When testes were exposed to toxicants, such as adjudin, the expression of P-glycoprotein was induced and the association of P-glycoprotein with occludin, claudin-11, and JAM-A was also significantly 'enhanced'. We hypothesize that this increase in protein-protein associations between P-glycoprotein and integral membrain proteins at the BTB may assist in 'sealing' the TJ-barrier at the BTB by pumping or keeping unwanted adjudin molecules out of the apical compartment (Fig. 2). However, adjudin, and possibly other environmental toxicants (e.g. cadmium) that manage to enter the apical compartment likely via other influx drug transporters, can still induce disruption of spermatid adhesion, analogous to the events of spermiation to allow premature release of spermatids from the epithelium. The hypothetical model depicted in Fig. 2 thus suggests that much research is needed to understand the biology and regulation of drug transporters in the testis in order to protect the testes from toxicant-induced testicular injury. However, drug transporters that 'safeguard' the immunological barrier (see Fig. 2) also pose a challenge for delivering contraceptives (e.g. adjudin) to the apical compartment of the epithelium behind the BTB to exert their effects (Cheng et al. 2005, Cheng \& Mruk 2010a). In short, influx and efflux pumps are acting in concert to determine the amount of drugs (e.g. male contraceptives and anticancer drugs) and/or harmful substances (e.g. environmental toxicants) available in the seminiferous epithelium behind the $\mathrm{BTB}$, analogous to the treatment of tumorigenesis and metastasis using chemotherapeutic drugs (Rochat 2009).

\section{Concluding remarks and future perspectives}

It is becoming increasingly clear that drug transporters are not limited to Sertoli cells in the testis that constitute the BTB. This illustrates that the developing germ cells are actively involved in 'pumping out' unwanted harmful substances from the seminiferous epithelium or preventing the entry of toxicants into developing germ cells, as well as in 'selecting/uptaking' necessary compounds for their development. However, the fact that there are a number of different types of drug transporters (see Table 2) in the testisicular Sertoli, Leydig, germ, and peritubular myoid cells (and it is obvious that many more drug transporters remain to be identified), poses a great challenge to the testis to protect spermatogenesis from harmful compounds and toxicants. For instance, a harmful substance/toxicant can gain entry to the apical compartment, traversing the BTB, via selected influx pumps even though they have been 'blocked' to cross the BTB by other efflux or influx pumps or they have been actively pumped out of Sertoli cells and/or germ cells. Once these toxicants enter the seminiferous epithelium, they can exert their effects rapidly by perturbing the actin cytoskeletal network (e.g. perturbing actin bundling or inducing actin nucleation) and accelerate protein endocytosis at the apical ES to cause the unwanted cascade of events analogous to spermiation that leads to premature germ cell exfoliation from the testis and possibly infertility. In short, this is a highly neglected area of research in male reproductive biology that requires additional studies.

\section{Declaration of interest}

The authors declare that there is no conflict of interest that could be perceived as prejudicing the impartiality of the research reported.

\section{Funding}

Studies performed in the authors' laboratory discussed herein were supported by grants from the National Institutes of Health (NICHD R01 HD056304 and R01 HD056034-02S1 to C Y C; U54 HD029990 Project 5 to C Y C; and R03 HD061401 to D D M). Due to space limitations, many of the important original research articles by colleagues and investigators in the field could not be cited, and recent reviews on appropriate subjects were used instead.

\section{Author contribution statement}

L S researched the topic and co-wrote the review; D M critically evaluated information and co-wrote the review; C Y C conceived the idea to prepare the review, researched the topic, critically evaluated information, and co-wrote the review.

\section{References}

Abe T, Kakyo M, Sakagami H, Tokui T, Nishio T, Tanemoto M, Nomura H, Hebert SC, Matsuno S, Kondo H et al. 1998 Molecular characterization and tissue distribution of a new organic anion transporter subtype (oatp3) that transports thyroid hormones and taurocholate and comparison with oatp2. Journal of Biological Chemistry 273 22395-22401. (doi:10.1074/jbc. 273.35.22395)

Alam MI, Beg S, Samad A, Baboota S, Kohli K, Ali J, Ahuja A \& Akbar M 2010 Strategy for effective brain drug delivery. European Journal of Pharmaceutical Sciences 40 385-403. (doi:10.1016/j.ejps.2010.05.003)

Allikmets R, Schriml LM, Hutchinson A, Romano-Spica V \& Dean M 1998 A human placenta-specific ATP-binding cassette gene (ABCP) on chromosome 4q22 that is involved in multidrug resistance. Cancer Research 58 5337-5339.

Almquist KC, Loe DW, Hipfner DR, Mackie JE, Cole SP \& Deeley RG 1995 Characterization of the $M(\mathrm{r}) 190,000$ multidrug resistance protein (MRP) in drug-selected and transfected human tumor cell. Cancer Research 55 102-110.

Aouida M, Poulin R \& Ramotar D 2010 The human carnitine transporter SLC22A16 mediates high affinity uptake of the anticancer polyamine analogue bleomycin-A5. Journal of Biological Chemistry 285 6275-6284. (doi:10.1074/jbc.M109.046151)

Augustine LM, Markelewicz RJJ, Boekelheide K \& Cherrington NJ 2005 Xenobiotic and endobiotic transporter mRNA expression in the bloodtestis barrier. Drug Metabolism and Disposition 33 182-189. (doi:10.1124/ dmd.104.001024)

Ban N, Sasaki M, Sakai H, Ueda K \& Inagaki N 2005 Cloning of ABCA17, a novel rodent sperm-specific ABC (ATP-binding cassette) transporter that regulates intracellular lipid metabolism. Biochemical Journal 389 577-585. (doi:10.1042/BJ20050159)

Bart J, Hollema H, Groen HJ, de Vries EG, Hendrikse NH, Sleijfer DT, Wegman TD, Vaalburg W \& van der Graaf WT 2004 The distribution of 
drug-efflux pumps, P-gp, BCRP, MRP1 and MRP2, in the normal bloodtestis barrier and in primary testicular tumours. European Journal of Cancer $\mathbf{4 0}$ 2064-2070. (doi:10.1016/j.ejca.2004.05.010)

Bera TK, Iavarone C, Kumar V, Lee S, Lee B \& Pastan I 2002 MRP9, an unusual truncated member of the $\mathrm{ABC}$ transporter superfamily, is highly expressed in breast cancer. PNAS 99 6997-7002. (doi:10.1073/pnas. 102187299)

Bermingham JRJ \& Pennington J 2004 Organization and expression of the SLC36 cluster of amino acid transporter genes. Mammalian Genome 15 114-125. (doi:10.1007/s00335-003-2319-3)

van der Bliek AM, Kooiman PM, Schneider C \& Borst P 1988 Sequence of mdr3 cDNA encoding a human P-glycoprotein. Gene 71 401-411. (doi:10. 1016/0378-1119(88)90057-1)

Boesch D, Gaveriaux C, Jachez B, Pourtier-Manzanedo A, Bollinger P \& Loor F 1991 In vivo circumvention of P-glycoprotein-mediated multidrug resistance of tumor cells with SDZ PSC833. Cancer Research 51 4226-4233.

Brower JV, Lim CH, Jorgensen M, Oh SP \& Terada N 2009 Adenine nucleotide translocase 4 deficiency leads to early meiotic arrest of murine male germ cells. Reproduction 138 463-470. (doi:10.1530/REP-09-0201)

Carreau S \& Hess RA 2010 Oestrogens and spermatogenesis. Philosophical Transactions of the Royal Society of London. Series B: Biological Sciences 365 1517-1535. (doi:10.1098/rstb.2009.0235)

Carreau S, Wolczynski S \& Galeraud-Denis I 2010 Aromatase, oestrogens and human male reproduction. Philosophical Transactions of the Royal Society of London. Series B: Biological Sciences 365 1571-1579. (doi:10.1098/rstb.2009. 0113)

Chauvin TR \& Griswold MD 2004 Characterization of the expression and regulation of genes necessary for myo-inositol biosynthesis and transport in the seminiferous epithelium. Biology of Reproduction 70 744-751. (doi:10. 1095/biolreprod.103.022731)

Chen ZQ, Annilo T, Shulenin S \& Dean M 2004 Three ATP-binding cassette transporter genes, Abca14, Abca15, and Abca16, form a cluster on mouse chromosome 7F3. Mammalian Genome 15 335-343. (doi:10.1007/s00335004-2281-8)

Cheng CY \& Mruk DD 2009 An intracellular trafficking pathway in the seminiferous epithelium regulating spermatogenesis: a biochemical and molecular perspective. Critical Reviews in Biochemistry and Molecular Biology 44 245-263. (doi:10.1080/10409230903061207)

Cheng CY \& Mruk DD 2010a The biology of spermatogenesis: the past, present and future. Philosophical Transactions of the Royal Society of London. Series B: Biological Sciences 365 1459-1463. (doi:10.1098/rstb.2010.0024)

Cheng CY \& Mruk DD 2010b A local autocrine axis in the testes that regulates spermatogenesis. Nature Reviews. Endocrinology 6 380-395. (doi:10.1038/nrendo.2010.71)

Cheng CY \& Mruk DD 2010c New frontiers in non-hormonal male contraception. Contraception 82 476-482. (doi:10.1016/j.contraception. 2010.03.017)

Cheng CY, Mruk D, Silvestrini B, Bonanomi M, Wong CH, Siu MK, Lee NP, Lui WY \& Mo MY 2005 AF-2364 [1-(2,4-dichlorobenzyl)-1H-indazole3 -carbohydrazide] is a potential male contraceptive: a review of recent data. Contraception 72 251-261. (doi:10.1016/j.contraception.2005.03.008)

Cheng CY, Wong EW, Yan HH \& Mruk DD 2010 Regulation of spermatogenesis in the microenvironment of the seminiferous epithelium: new insights and advances. Molecular and Cellular Endocrinology 315 49-56. (doi:10.1016/j.mce.2009.08.004)

Choudhuri S \& Klaassen CD 2006 Structure, function, expression, genomic organization, and single nucleotide polymorphisms of human $\mathrm{ABCB} 1$ (MDR1), ABCC (MRP), and ABCG2 (BCRP) efflux transporters. International Journal of Toxicology 25 231-259. (doi:10.1080/ $10915810600746023)$

Cole SP, Bhardwaj G, Gerlach JH, Mackie JE, Grant CE, Almquist KC, Stewart AJ, Kurz EU, Duncan AM \& Deeley RG 1992 Overexpression of a transporter gene in a multidrug-resistant human lung cancer cell line. Science 258 1650-1654. (doi:10.1126/science.1360704)

Couture L, Nash JA \& Turgeon J 2006 The ATP-binding cassette transporters and their implication in drug disposition: a special look at the heart. Pharmacological Reviews 58 244-258. (doi:10.1124/pr.58.2.7)
Croop JM, Raymond M, Haber D, Devault A, Arceci RJ, Gros P \& Housman DE 1989 The three mouse multidrug resistance (mdr) genes are expressed in a tissue-specific manner in normal mouse tissues. Molecular and Cellular Biology 9 1346-1350.

Crowley E \& Callaghan R 2009 Multidrug efflux pumps: drug binding - gates or cavity? FEBS Journal 277 530-539. (doi:10.1111/j.1742-4658.2009. 07484.x)

Dallas S, Miller DS \& Bendayan R 2006 Multidrug resistance-associated proteins: expression and function in the central nervous system. Pharmacological Reviews 58 140-161. (doi:10.1124/pr.58.2.3)

Dalton TP, He L, Wang B, Miller ML, Jin L, Stringer KF, Chang X, Baxter CS \& Nebert DW 2005 Identification of mouse SLC39A8 as the transporter responsible for cadmium-induced toxicity in the testis. PNAS 102 3401-3406. (doi:10.1073/pnas.0406085102)

Dean M, Rzhetsky A \& Allikmets R 2001 The human ATP-binding cassette (ABC) transporter superfamily. Genome Research 11 1156-1166. (doi:10. 1101/gr.GR-1649R)

Delclos KB, Bucci TJ, Lomax LG, Latendresse JR, Warbritton A, Weis CC \& Newbold RR 2001 Effects of dietary genistein exposure during development on male and female CD (Sprague-Dawley) rats. Reproductive Toxicology 15 647-663. (doi:10.1016/S0890-6238(01)00177-0)

Doyle LA, Yang W, Abruzzo LV, Krogmann T, Gao Y, Rishi AK \& Ross DD 1998 A multidrug resistance transporter from human MCF-7 breast cancer cells. PNAS 95 15665-15670. (doi:10.1073/pnas.95.26.15665)

Elgazar V, Razanov V, Stoltenberg M, Hershfinkel M, Huleihel M, Nitzan YB, Lunenfeld E, Sekler I \& Silverman WF 2005 Zinc-regulating proteins, ZnT-1, and metallothionein I/II are present in different cell populations in the mouse testis. Journal of Histochemistry and Cytochemistry 53 905-912. (doi:10.1369/jhc.4A6482.2005)

Elliott AM \& Al-Hajj MA 2009 ABCB8 mediates doxorubicin resistance in melanoma cells by protecting the mitochondrial genome. Molecular Cancer Research 7 79-87. (doi:10.1158/1541-7786.MCR-08-0235)

Enokizono J, Kusuhara H \& Sugiyama Y 2007 Effect of breast cancer resistance protein (Bcrp/Abcg2) on the disposition of phytoestrogens. Molecular Pharmacology 72 967-975. (doi:10.1124/mol.107.034751)

Enokizono J, Kusuhara H, Ose A, Schinkel AH \& Sugiyama Y 2008 Quantitative investigation of the role of breast cancer resistance protein (Bcrp/Abcg2) in limiting brain and testis penetration of xenobiotic compounds. Drug Metabolism and Disposition 36 995-1002. (doi:10.1124/ dmd.107.019257)

Enomoto A, Wempe MF, Tsuchida H, Shin HJ, Cha SH, Anzai N, Goto A, Sakamoto A, Niwa T, Kanai Y et al. 2002 Molecular identification of a novel carnitine transporter specific to human testis. Insights into the mechanism of carnitine recognition. Journal of Biological Chemistry 277 36262-36271. (doi:10.1074/jbc.M203883200)

Evers R, Zaman GJ, van Deemter L, Jansen H, Calafat J, Oomen LC, Oude Elferink RP, Borst P \& Schinkel AH 1996 Basolateral localization and export activity of the human multidrug resistance-associated protein in polarized pig kidney cells. Journal of Clinical Investigation 97 1211-1218. (doi:10.1172/JCI118535)

Fardel O \& Le Vee M 2009 Regulation of human drug transporter expression by pro-inflammatory cytokines. Expert Opinion on Drug Metabolism and Toxicology 5 1469-1481. (doi:10.1517/17425250903304056)

Fahrmayr C, Fromm MF \& Konig J 2010 Hepatic OATP and OCT uptake transporters: their role for drug-drug interactions and pharmacogenetic aspects. Drug Metabolism Reviews 42 380-401. (doi:10.3109/03602530903 491683)

Fetsch PA, Abati A, Litman T, Morisaki K, Honjo Y, Mittal K \& Bates SE 2006 Localization of the ABCG2 mitoxantrone resistance-associated protein in normal tissues. Cancer Letters 235 84-92. (doi:10.1016/j.canlet. 2005.04.024)

Fitzgerald ML, Mujawar Z \& Tamehiro N 2010 ABC transporters, atherosclerosis and inflammation. Atherosclerosis 211 361-370. (doi:10. 1016/j.atherosclerosis.2010.01.011)

Flens MJ, Izquierdo MA, Scheffer GL, Fritz JM, Meijer CJ, Scheper RJ \& Zaman GJ 1994 Immunochemical detection of the multidrug resistanceassociated protein MRP in human multidrug-resistant tumor cells by monoclonal antibodies. Cancer Research 54 4557-4563. 
Flens MJ, Zaman GJ, van der Valk P, Izquierdo MA, Schroeijers AB, Scheffer GL, van der Groep P, de Haas M, Meijer CJ \& Scheper RJ 1996 Tissue distribution of the multidrug resistance protein. American Journal of Pathology 148 1237-1247.

Ford JM 1995 Modulators of multidrug resistance. Preclinical studies. Hematology/Oncology Clinics of North America 9 337-361.

Franke RM, Gardner ER \& Sparreboom A 2010 Pharmacogenetics of drug transporters. Current Pharmaceutical Design 16 220-230. (doi:10.2174/ 138161210790112683)

Fromm MF 2004 Importance of P-glycoprotein at blood-tissue barriers. Trends in Pharmacological Sciences 25 423-429. (doi:10.1016/j.tips.2004. 06.002)

Ganta S, Deshpande D, Korde A \& Amiji M 2010 A review of multifunctional nanoemulsion systems to overcome oral and CNS drug delivery barriers. Molecular Membrane Biology 27 260-273. (doi:10.3109/09687688.2010. 497971)

Gaucher G, Satturwar P, Jones M-C, Furtos A \& Leroux J-C 2010 Polymeric micelles for oral drug delivery. European Journal of Pharmacentics and Biopharmaceutics 76 147-158. (doi:10.1016/j.ejpb.2010.06.007)

Green MM 2010 2010: a century of Drosophila genetics through the prism of the white gene. Genetics 184 3-7. (doi:10.1534/genetics.109.110015)

Grichtchenko II, Choi I, Zhong X, Bray-Ward P, Russell JM \& Boron WF 2001 Cloning, characterization, and chromosomal mapping of a human electroneutral $\mathrm{Na}(+)$-driven $\mathrm{Cl}-\mathrm{HCO}_{3}$ exchanger. Journal of Biological Chemistry 276 8358-8363. (doi:10.1074/jbc.C000716200)

Griffin KP, Ward DT, Liu W, Stewart G, Morris ID \& Smith CP 2005 Differential expression of divalent metal transporter DMT1 (Slc11a2) in the spermatogenic epithelium of the developing and adult rat testis. American Journal of Physiology. Cell Physiology 288 C176-C184. (doi:10.1152/ajpcell. 00061.2004)

Gros P, Raymond M, Bell J \& Housman D 1988 Cloning and characterization of a second member of the mouse mdr gene family. Molecular and Cellular Biology 8 2770-2778.

Hess RA \& de Franca LR 2008 Spermatogenesis and cycle of the seminiferous epithelium. In Molecular Mechanisms in Spermatogenesis, pp 1-15. Ed. CY Cheng. Austin, TX: Landes Bioscience/Springer Science + Business Media, LLC.

Hipfner DR, Gauldie SD, Deeley RG \& Cole SP 1994 Detection of the $M(\mathrm{r})$ 190,000 multidrug resistance protein, MRP, with monoclonal antibodies. Cancer Research 54 5788-5792.

Höftberger R, Kunze M, Weinhofer I, Aboul-Enein F, Voigtländer T, Oezen I, Amann G, Bernheimer H, Budka H \& Berger J 2007 Distribution and cellular localization of adrenoleukodystrophy protein in human tissues: implications for X-linked adrenoleukodystrophy. Neurobiology of Disease $\mathbf{2 8}$ 165-174. (doi:10.1016/j.nbd.2007.07.007)

Hu JH, He XB \& Yan YC 2000 Identification of $\gamma$-aminobutyric acid transporter (GAT1) on the rat sperm. Cell Research 10 51-58. (doi:10.1038/ sj.cr.7290035)

Hu JH, Yang N, Ma YH, Jiang J, Zhang JF, Fei J \& Guo LH 2004 Identification of glutamate transporters and receptors in mouse testis. Acta Pharmacologica Sinica 25 366-371.

Hu GX, Hu LF, Yang DZ, Li JW, Chen GR, Chen BB, Mruk DD, Bonanomi M, Silvestrini B, Cheng CY et al. 2009 Adjudin targeting rabbit germ cell adhesion as a male contraceptive: a pharmacokinetics study. Journal of Andrology 30 87-93. (doi:10.2164/jandrol.108.004994)

Huisman MT, Smit JW, Crommentuyn KM, Zelcer N, Wiltshire HR, Beijnen JH \& Schinkel AH 2002 Multidrug resistance protein 2 (MRP2) transports HIV protease inhibitors, and transport can be enhanced by other drugs. AIDS 16 2295-2301. (doi:10.1097/00002030-20021122000009)

Ibberson M, Riederer BM, Uldry M, Guhl B, Roth J \& Thorens B 2002 Immunolocalization of GLUTX1 in the testis and to specific brain areas and vasopressin-containing neurons. Endocrinology 143 276-284. (doi:10.1210/ en.143.1.276)

Inagaki N, Gonoi T, Clement JP, Wang CZ, Aguilar-Bryan L, Bryan J \& Seino S 1996 A family of sulfonylurea receptors determines the pharmacological properties of ATP-sensitive $\mathrm{K}^{+}$channels. Neuron 16 1011-1017. (doi:10. 1016/S0896-6273(00)80124-5)
Jégou B 1992 The Sertoli cell. Bailliere's Clinical Endocrinology and Metabolism 6 273-311. (doi:10.1016/S0950-351X(05)80151-X)

Jeulin C \& Lewin LM 1996 Role of free L-carnitine and acetyl-L-carnitine in post-gonadal maturation of mammalian spermatozoa. Human Reproduction Update 2 87-102. (doi:10.1093/humupd/2.2.87)

Jonker JW \& Schinkel AH 2004 Pharmacological and physiological functions of the polyspecific organic cation transporters: OCT1, 2, and 3 (SLC22A1-3). Journal of Pharmacology and Experimental Therapentics 308 2-9. (doi:10.1124/jpet.103.053298)

Jonker JW, Smit JW, Brinkhuis RF, Maliepaaed M, Beijnen JH, Schellens JH \& Schinkel AH 2000 Role of breast cancer resistance protein in the bioavailability and fetal penetration of topotecan. Journal of the National Cancer Institute 92 1651-1656. (doi:10.1093/jnci/92.20.1651)

Jonker JW, Wagenaar E, Mol CA, Buitelaar M, Koepsell H, Smit JW \& Schinkel AH 2001 Reduced hepatic uptake and intestinal excretion of organic cations in mice with a targeted disruption of the organic cation transporter 1 (Oct1 [Slc22a1]) gene. Molecular and Cellular Biology 21 5471-5477. (doi:10.1128/MCB.21.16.5471-5477.2001)

Jonker JW, Wagenaar E, van Eijl S \& Schinkel AH 2003 Deficiency in the organic cation transporters 1 and 2 (Oct1/Oct2 [Slc22a1/Slc22a2]) in mice abolishes renal secretion of organic cations. Molecular and Cellular Biology 23 7902-7908. (doi:10.1128/MCB.23.21.7902-7908.2003)

Kaisman-Elbaz T, Sekler I, Fishman D, Karol N, Forberg M, Kahn N, Hershfinkel M \& Silverman WF 2009 Cell death induced by zinc and cadmium is mediated by clusterin in cultured mouse seminiferous tubules. Journal of Cellular Physiology 220 222-229. (doi:10.1002/jcp.21754)

Kalliokoski A \& Niemi M 2009 Impact of OATP transporters on pharmacokinetics. British Journal of Pharmacology 158 693-705. (doi:10. 1111/j.1476-5381.2009.00430.x)

Keppler D, Leier I \& Jedlitschky G 1997 Transport of glutathione conjugates and glucuronides by the multidrug resistance proteins MRP1 and MRP2. Biological Chemistry 378 787-791.

Keppler D, Cui Y, König J, Leier I \& Nies A 1999 Export pumps for anionic conjugates encoded by MRP genes. Advances in Enzyme Regulation 39 237-246. (doi:10.1016/S0065-2571(98)00015-6)

Kim ST \& Moley KH 2007 The expression of GLUT8, GLUT9a, and GLUT9b in the mouse testis and sperm. Reproductive Sciences 14 445-455. (doi:10.1177/1933719107306228)

Kis O, Robillard K, Chan GN \& Bendayan R 2010 The complexities of antiretroviral drug-drug interactions: role of $\mathrm{ABC}$ and SLC transporters. Trends in Pharmacological Sciences 31 22-35. (doi:10.1016/ j.tips.2009.10.001)

Klaassen CD \& Aleksunes LM 2010 Xenobiotic, bile acid, and cholesterol transporters: function and regulation. Pharmacological Reviews 62 1-96. (doi:10.1124/pr.109.002014)

Klein T, Cooper TG \& Yeung CH 2006 The role of potassium chloride cotransporters in murine and human sperm volume regulation. Biology of Reproduction 75 853-858. (doi:10.1095/biolreprod.106.054064)

Kobayashi D, Goto A, Maeda T, Nezu J, Tsuji A \& Tamai I 2005 OCTN2mediated transport of carnitine in isolated Sertoli cells. Reproduction 129 729-736. (doi:10.1530/rep.1.00507)

Kobayashi D, Tamai I, Sai Y, Yoshida K, Wakayama T, Kido Y, Nezu J, Iseki S \& Tsuji A 2007 Transport of carnitine and acetylcarnitine by carnitine/organic cation transporter (OCTN) 2 and OCTN3 into epididymal spermatozoa. Reproduction 134 651-658. (doi:10.1530/REP06-0173)

Koepsell H, Lips K \& Volk C 2007 Polyspecific organic cation transporters: structure, function, physiological roles, and biopharmaceutical implications. Pharmaceutical Research 24 1227-1251. (doi:10.1007/s11095-0079254-z)

König J, Rost D, Cui Y \& Keppler D 1999 Characterization of the human multidrug resistance protein isoform MRP3 localized to the basolateral hepatocyte membrane. Hepatology 29 1156-1163. (doi:10.1002/hep. 510290404)

Kool M, van der Linden M, de Haas M, Scheffer GL, de Vree JM, Smith AJ, Jansen G, Peters GJ, Ponne N, Scheper RJ et al. 1999 MRP3, an organic anion transporter able to transport anti-cancer drugs. PNAS 96 6914-6919. (doi:10.1073/pnas.96.12.6914) 
Koshiba S, An R, Saito H, Wakabayashi K, Tamura A \& Ishikawa T 2008 Human ABC transporters ABCG2 (BCRP) and ABCG4. Xenobiotica 38 863-888. (doi:10.1080/00498250801986944)

de Kretser DM \& Kerr JB 1988 The cytology of the testis. In: The Physiology of Reproduction, vol 1, pp 837-932. Eds E Knobil, JB Neill, LL Ewing, GS Greenwald, CL Markert \& DW Pfaff. New York: Raven Press.

Krishnamachary N, Ma L, Zheng L, Safa AR \& Center MS 1994 Analysis of MRP gene expression and function in HL60 cells isolated for resistance to adriamycin. Oncology Research 6 119-127.

Krishnamurthy PC, Du G, Fukuda Y, Sun D, Sampath J, Mercer KE, Wang J, Sosa-Pineda B, Murti KG \& Schuetz JD 2006 Identification of a mammalian mitochondrial porphyrin transporter. Nature 443 586-589. (doi:10.1038/nature05092)

Kyselova V, Peknicova J, Boubelik M \& Buckiova D 2004 Body and organ weight, sperm acrosomal status and reproduction after genistein and diethylstilbestrol treatment of CD1 mice in a multigenerational study. Theriogenology 61 1307-1325. (doi:10.1016/j.theriogenology.2003.07.017)

Lassalle B, Bastos H, Louis JP, Riou L, Testart J, Dutrillaux B, Fouchet P \& Allemand I 2004 'Side Population' cells in adult mouse testis express Bcrp1 gene and are enriched in spermatogonia and germinal stem cells. Development 131 479-487. (doi:10.1242/dev.00918)

Lautier D, Canitrot Y, Deeley RG \& Cole SP 1996 Multidrug resistance mediated by the multidrug resistance protein (MRP) gene. Biochemical Pharmacology 52 967-977. (doi:10.1016/0006-2952(96)00450-9)

Leslie EM, Deeley RG \& Cole SP 2005 Multidrug resistance proteins: role of P-glycoprotein, MRP1, MRP2, and BCRP (ABCG2) in tissue defense. Toxicology and Applied Pharmacology 204 216-237. (doi:10.1016/j.taap.2004. 10.012)

Leuthold S, Hagenbuch B, Mohebbi N, Wagner CA, Meier PJ \& Stieger B 2009 Mechanisms of $\mathrm{pH}$-gradient driven transport mediated by organic anion polypeptide transporters. American Journal of Physiology. Cell Physiology 296 C570-C582. (doi:10.1152/ajpcell.00436.2008)

Lhuillier P, Rode B, Escalier D, Lorès P, Dirami T, Bienvenu T, Gacon G, Dulioust E \& Touré A 2009 Absence of annulus in human asthenozoospermia: case report. Human Reproduction 24 1296-1303. (doi:10.1093/ humrep/dep020)

Li L, Meier PJ \& Ballatori N 2000 Oatp2 mediates bidirectional organic solute transport: a role for intracellular glutathione. Molecular Pharmacology $58335-340$.

Li MW, Mruk DD, Lee WM \& Cheng CY 2009 Cytokines and junction restructuring events during spermatogenesis in the testis: an emerging concept of regulation. Cytokine \& Growth Factor Reviews 20 329-338. (doi:10.1016/j.cytogfr.2009.07.007)

Li Y, Yuan H, Yang K, Xu W, Tang W \& Li X 2010 The structure and function of P-glycoprotein. Current Medicinal Chemistry 17 786-800. (doi:10.2174/092986710790514507)

Loe DW, Almquist KC, Deeley RG \& Cole SP 1996 Multidrug resistance protein (MRP)-mediated transport of leukotriene $\mathrm{C} 4$ and chemotherapeutic agents in membrane vesicles. Demonstration of glutathione-dependent vincristine transport. Journal of Biological Chemistry 271 9675-9682. (doi:10.1074/jbc.271.44.27782)

Lohi H, Kujala M, Makela S, Lehtonen E, Kestila M, Saarialho-Kere U, Markovich D \& Kere J 2002 Functional characterization of three novel tissue-specific anion exchangers SLC26A7, -A8, and -A9. Journal of Biological Chemistry 277 14246-14254. (doi:10.1074/jbc.M111802200)

Lorico A, Bertola A, Baum C, Fodstad O \& Rappa G 2002 Role of the multidrug resistance protein 1 in protection from heavy metal oxyanions: investigations in vitro and in MRP1-deficient mice. Biochemical and Biophysical Research Communications 291 617-622. (doi:10.1006/bbrc.2002. 6489)

Maeda T, Goto A, Kobayashi D \& Tamai I 2007 Transport of organic cations across the blood-testis barrier. Molecular Pharmaceutics 4 600-607. (doi:10. $1021 / \mathrm{mp} 0700231$ )

Maliepaard M, Scheffer GL, Faneyte IF, van Gastelen MA, Pijnenborg AC, Schinkel AH, van De Vijver MJ, Scheper RJ \& Schellens JH 2001 Subcellular localization and distribution of the breast cancer resistance protein transporter in normal human tissues. Cancer Research 61 3458-3464.
Marzolini C, Paus E, Buclin T \& Kim RB 2004 Polymorphisms in human MDR1 (P-glycoprotein): recent advances and clinical relevance. Clinical Pharmacology and Therapeutics 75 13-33. (doi:10.1016/j.clpt.2003.09.012)

McMahon RJ \& Cousins RJ 1998 Mammalian zinc transporters. Journal of Nutrition 128 667-670.

Meinhardt A \& Hedger MP 2010 Immunological, paracrine and endocrine aspects of testicular immune privilege. Molecular and Cellular Endocrinology. (doi:10.1016/j.mce.2010.03.022)

Melaine N, Lienard MO, Dorval I, Le Goascogne C, Lejeune H \& Jegou B 2002 Multidrug resistance genes and p-glycoprotein in the testis of the rat, mouse, guinea pig, and human. Biology of Reproduction 67 1699-1707. (doi:10.1095/biolreprod.102.003558)

Melaine N, Satie AP, Lassurguère J, Desmots S, Jégou B \& Samson M 2006 Molecular cloning of several rat $\mathrm{ABC}$ transporters including a new $\mathrm{ABC}$ transporter, $\mathrm{Abcb8}$, and their expression in rat testis. International Journal of Andrology 29 392-399. (doi:10.1111/j.1365-2605.2005.00616.x)

Mikkaichi T, Suzuki T, Onogawa T, Tanemoto M, Mizutamari H, Okada M, Chaki T, Masuda S, Tokui T, Eto N et al. 2004 Isolation and characterization of a digoxin transporter and its rat homologue expressed in the kidney. PNAS 101 3569-3574. (doi:10.1073/pnas.0304987101)

Miller DS 2010 Regulation of P-glycoprotein and other ABC drug transporters at the blood-brain barrier. Trends in Pharmacological Sciences $\mathbf{3 1}$ 246-254. (doi:10.1016/j.tips.2010.03.003)

Miller DS, Bauer B \& Hartz AM 2008 Modulation of P-glycoprotein at the blood-brain barrier: opportunities to improve central nervous system pharmacotherapy. Pharmacological Reviews 60 196-209. (doi:10.1124/pr. 107.07109)

Morales CR, Marat AL, Ni X, Yu Y, Oko R, Smith BT \& Argraves WS 2008 ATP-binding, cassette transporters ABCA1, ABCA7, and ABCG1 in mouse spermatozoa. Biochemical and Biophysical Research Communications 376 472-477. (doi:10.1016/j.bbrc.2008.09.009)

Morrow CM, Mruk DD, Cheng CY \& Hess RA 2010 Claudin and occludin expression and function in the seminiferous epithelium. Philosophical Transactions of the Royal Society of London. Series B: Biological Sciences 365 1679-1696. (doi:10.1098/rstb.2010.0025)

Mruk DD \& Cheng CY 2010 Tight junctions in the testis: new perspectives. Philosophical Transactions of the Royal Society of London. Series B: Biological Sciences 365 1621-1635. (doi:10.1098/rstb.2010.0010)

Mruk DD, Silvestrini B \& Cheng CY 2008 Anchoring junctions as drug targets: role in contraceptive development. Pharmacological Reviews 60 146-180. (doi:10.1124/pr.107.07105)

Muller MB, Keck ME, Binder EB, Kresse AE, Hagemeyer TP, Landgraf R, Holsboer F \& Uhr M 2003 ABCB1 (MDR1)-type P-glycoproteins at the blood-brain barrier modulate the activity of the hypothalamicpituitary-adrenocortical system: implications for affective disorder. Neuropsychopharmacology 28 1991-1999. (doi:10.1038/sj.npp.1300257)

Nenicu A, Lüers GH, Kovacs W, David M, Zimmer A, Bergmann M \& Baumgart-Vogt E 2007 Peroxisomes in human and mouse testis: differential expression of peroxisomal proteins in germ cells and distinct somatic cell types of the testis. Biology of Reproduction 77 1060-1072. (doi:10.1095/ biolreprod.107.061242)

Ni Z, Bikadi Z, Rosenberg MF \& Mao Q 2010 Structure and function of the human breast cancer resistance protein (BCRP/ABCG2). Current Drug Metabolism 11 603-617. (doi:10.2174/138920010792927325)

Nishimura M \& Naito S 2005 Tissue-specific mRNA expression profiles of human ATP-binding cassette and solute carrier transporter superfamilies. Drug Metabolism and Pharmacokinetics 20 452-477. (doi:10.2133/ dmpk.20.452)

Nishino J, Suzuki H, Sugiyama D, Kitazawa T, Ito K, Hanano M \& Sugiyama Y 1999 Transepithelial transport of organic anions across the choroid plexus: possible involvement of organic anion transporter and multidrug resistance-associated protein. Journal of Pharmacology and Experimental Therapeutics $290289-294$.

Ohtsuki S, Takizawa T, Takanaga H, Hori S, Hosoya K \& Terasaki T 2004 Localization of organic anion transporting polypeptide 3 (oatp3) in mouse brain parenchymal and capillary endothelial cells. Journal of Neurochemistry 90 743-749. (doi:10.1111/j.1471-4159.2004.02549.x) 
Ono N, Van der Heijden I, Scheffer GL, van de Wetering K, van Deemter E, De Haas M, Boerke A, Gadella BM, De Rooij DG, Neefjes JJ et al. 2007 Multidrug resistance-associated protein 9 (ABCC12) is present in mouse and boar sperm. Biochemical Journal 406 31-40. (doi:10.1042/BJ20070292)

Petry F, Ritz V, Meineke C, Middel P, Kietzmann T, Schmitz-Salue C \& Hirsch-Ernst KI 2006 Subcellular localization of rat Abca5, a rat ATPbinding-cassette transporter expressed in Leydig cells, and characterization of its splice variant apparently encoding a half-transporter. Biochemical Journal 393 79-87. (doi:10.1042/BJ20050808)

Pizzagalli F, Hagenbuch B, Stieger B, Klenk U, Folkers G \& Meier PJ 2002 Identification of a novel human organic anion transporting polypeptide as a high affinity thyroxine transporter. Molecular Endocrinology 16 2283-2296. (doi:10.1210/me.2001-0309)

Pritchard JB \& Miller DS 1993 Mechanisms mediating renal secretion of organic anions and cations. Physiological Reviews 73 765-796.

Rappa G, Finch RA, Sartorelli AC \& Lorico A 1999 New insights into the biology and pharmacology of the multidrug resistance protein (MRP) from gene knockout models. Biochemical Pharmacology 58 557-562. (doi:10.1016/ S0006-2952(99)00074-X)

Renes J, de Vries EG, Nienhuis EF, Jansen PL \& Muller M 1999 ATPand glutathione-dependent transport of chemotherapeutic drugs by the multidrug resistance protein MRP1. British Journal of Pharmacology 126 681-688. (doi:10.1038/sj.bjp.0702360)

Rochat B 2009 Importance of influx and efflux systems and xenobiotic metabolizing enzymes in intratumoral disposition of anticancer agents. Current Cancer Drug Targets 9 652-674. (doi:10.2174/1568009097890 56999)

Roelofsen H, Vos TA, Schippers IJ, Kuipers F, Koning H, Moshage H, Jansen PL \& Müller M 1997 Increased levels of the multidrug resistance protein in lateral membranes of proliferating hepatocyte-derived cells. Gastroenterology 112 511-521. (doi:10.1053/gast.1997.v112.pm9024305)

Ross DD \& Nakanishi T 2010 Impact of breast cancer resistance protein on cancer treatment outcomes. Methods in Molecular Biology 596 251-290. (doi:10.1007/978-1-60761-416-6_12)

Ruetz S \& Gros P 1994 Phosphatidylcholine translocase: a physiological role for the mdr2 gene. Cell 77 1071-1081. (doi:10.1016/0092-8674(94) 90446-4)

Schaub TP, Kartenbeck J, König J, Vogel O, Witzgall R, Kriz W \& Keppler D 1997 Expression of the conjugate export pump encoded by the mrp2 gene in the apical membrane of kidney proximal tubules. Journal of the American Society of Nephrology 8 1213-1221.

Schinkel AH 1999 P-Glycoprotein, a gatekeeper in the blood-brain barrier. Advanced Drug Delivery Reviews 36 179-194. (doi:10.1016/S0169-409X(98) 00085-4)

Schinkel AH \& Jonker JW 2003 Mammalian drug efflux transporters of the ATP binding cassette (ABC) family: an overview. Advanced Drug Delivery Reviews 55 3-29. (doi:10.1016/S0169-409X(02)00169-2)

Schinkel AH, Wagenaar E, Mok CA \& van Deemter L 1996 P-glycoprotein in the blood-brain barrier of mice influences the brain penetration and pharmacological activity of many drugs. Journal of Clinical Investigation $\mathbf{9 7}$ 2517-2524. (doi:10.1172/JCI118699)

Schmitt BM \& Koepsell H 2005 Alkali cation binding and permeation in the rat organic cation transporter rOCT2. Journal of Biological Chemistry $\mathbf{2 8 0}$ 24481-24490. (doi:10.1074/jbc.M414550200)

Sekine T, Cha SH \& Endou H 2000 The multispecific organic anion transporter (OAT) family. Pflügers Archiv: European Journal of Physiology $\mathbf{4 4 0}$ 337-350. (doi:10.1007/s004240000297)

Selva DM, Hirsch-Reinshagen V, Burgess B, Zhou S, Chan J, McIsaac S, Hayden MR, Hammond GL, Vogl AW \& Wellington CL 2004 The ATPbinding cassette transporter 1 mediates lipid efflux from Sertoli cells and influences male fertility. Journal of Lipid Research 45 1040-1050. (doi:10. 1194/jlr.M400007-JLR200)

Setchell BP 2008 Blood-testis barrier, junctional and transport proteins and spermatogenesis. In Molecular Mechanisms in Spermatogenesis, pp 212-233. Ed. CY Cheng. Austin, TX: Landes Bioscience/Springer Science+ Business Media, LLC.
Shaha C 2008 Estrogens and spermatogenesis. In Molecular Mechanisms in Spermatogenesis, pp 42-64. Ed. CY Cheng. Austin, TX: Landes Bioscience/Springer Science + Business Media, LLC.

Sharpe RM 1994 Regulation of spermatogenesis. In The Physiology of Reproduction, pp 1363-1434. Eds E Knobil \& JD Neill. New York, NY: Raven Press.

Shen S \& Zhang W 2010 ABC transporters and drug efflux at the blood-brain barrier. Reviews in the Neurosciences 21 29-53.

Shukla S, Ohnuma S \& Ambudkar SW 2010 Improving cancer chemotherapy with modulators of ABP drug transporters. Current Drug Targets (In Press).

Smit JJ, Schinkel AH, Oude Elferink RP, Groen AK, Wagenaar E, van Deemter L, Mol CA, Ottenhoff R, van der Lugt NM, van Roon MA et al. 1993 Homozygous disruption of the murine mdr2 P-glycoprotein gene leads to a complete absence of phospholipid from bile and to liver disease. Cell 75 451-462. (doi:10.1016/0092-8674(93)90380-9)

Stewart PA, Beliveau R \& Rogers KA 1996 Cellular localization of P-glycoprotein in brain versus gonadal capillaries. Journal of Histochemistry and Cytochemistry 44 679-685. (doi:10.1177/44.7.8675989)

St-Pierre MV, Serrano MA, Macias RI, Dubs U, Hoechli M, Lauper U, Meier PJ \& Marin JJ 2000 Expression of members of the multidrug resistance protein family in human term placenta. American Journal of Physiology. Regulatory, Integrative and Comparative Physiology 279 R1495-R1503.

Su L, Cheng CY \& Mruk DD 2009 Drug transporter, P-glycoprotein (MDR1), is an integrated component of the mammalian blood-testis barrier. International Journal of Biochemistry and Cell Biology 41 2578-2587. (doi:10.1016/j.biocel.2009.08.015)

Suzuki T, Onogawa T, Asano N, Mizutamari H, Mikkaichi T, Tanemoto M, Abe M, Satoh F, Unno M, Nunoki K et al. 2003 Identification and characterization of novel rat and human gonad-specific organic anion transporters. Molecular Endocrinology 17 1203-1215. (doi:10.1210/me.20020304)

Tamai I, Ohashi R, Nezu JI, Sai Y, Kobayashi D, Oku A, Shimane M \& Tsuji A 2000 Molecular and functional characterization of organic cation/carnitine transporter family in mice. Journal of Biological Chemistry 275 40064-40072. (doi:10.1074/jbc.M005340200)

Tamai I, China K, Sai Y, Kobayashi D, Nezu J, Kawahara E \& Tsuji A 2001 $\mathrm{Na}(+)$-coupled transport of L-carnitine via high-affinity carnitine transporter OCTN2 and its subcellular localization in kidney. Biochimica et Biophysica Acta 1512 273-284. (doi:10.1016/S00052736(01)00328-5)

Tanaka Y, Slitt AL, Leazer TM, Maher JM \& Klaassen CD 2005 Tissue distribution and hormonal regulation of the breast cancer resistance protein (Bcrp/Abcg2) in rats and mice. Biochemical and Biophysical Research Communications 326 181-187. (doi:10.1016/j.bbrc.2004.11.012)

Thiebaut F, Tsuruo T, Hamada H, Gottesman MM, Pastan I \& Willingham MC 1987 Cellular localization of the multidrug-resistance gene product P-glycoprotein in normal human tissues. PNAS 84 7735-7738. (doi:10. 1073/pnas.84.21.7735)

Tomi M \& Hosoya KI 2010 The role of blood-ocular barrier transporters in retinal drug disposition: an overview. Expert Opinion on Drug Metabolism and Toxicology 6 1111-1124. (doi:10.1517/17425255.2010.486401)

Toure A, Morin L, Pineau C, Becq F, Dorseuil O \& Gacon G 2001 Tat1, a novel sulfate transporter specifically expressed in human male germ cells and potentially linked to rhogtpase signaling. Journal of Biological Chemistry 276 20309-20315. (doi:10.1074/jbc.M011740200)

Touré A, Lhuillier P, Gossen JA, Kuil CW, Lhôte D, Jégou B, Escalier D \& Gacon G 2007 The testis anion transporter 1 (Slc26a8) is required for sperm terminal differentiation and male fertility in the mouse. Human Molecular Genetics 16 1783-1793. (doi:10.1093/hmg/ddm117)

Traba J, Satrústegui J \& del Arco A 2009 Characterization of SCaMC-3like/slc25a41, a novel calcium-independent mitochondrial ATP-Mg/Pi carrier. Biochemical Journal 418 125-133. (doi:10.1042/BJ20081262)

Trezise AE \& Buchwald M 1991 In vivo cell-specific expression of the cystic fibrosis transmembrane conductance regulator. Nature 353 434-437. (doi:10.1038/353434a0)

Trezise AE, Romano PR, Gill DR, Hyde SC, Sepúlveda FV, Buchwald M \& Higgins CF 1992 The multidrug resistance and cystic fibrosis genes have complementary patterns of epithelial expression. EMBO Journal 11 4291-4303. 
Tribull TE, Bruner RH \& Bain LJ 2003 The multidrug resistance-associated protein 1 transports methoxychlor and protects the seminiferous epithelium from injury. Toxicology Letters 142 61-70. (doi:10.1016/S0378-4274(02) 00485-X)

Walters HC, Craddock AL, Fusegawa H, Willingham MC \& Dawson PA 2000 Expression, transport properties, and chromosomal location of organic anion transporter subtype 3. American Journal of Physiology. Gastrointestinal and Liver Physiology 279 G1188-G1200.

Westlake CJ, Qian YM, Gao M, Vasa M, Cole SP \& Deeley RG 2003 Identification of the structural and functional boundaries of the multidrug resistance protein 1 cytoplasmic loop 3. Biochemistry 42 14099-14113. (doi:10.1021/bi035333y)

Wijnholds J, Scheffer GL, van der Valk M, van der Valk P, Beijnen JH, Scheper RJ \& Borst P 1998 Multidrug resistance protein 1 protects the oropharyngeal mucosal layer and the testicular tubules against drug-induced damage. Journal of Experimental Medicine 188 797-808. (doi:10.1084/jem. 188.5.797)

Wisniewski AB, Klein SL, Lakshmanan Y \& Gearhart JP 2003 Exposure to genistein during gestation and lactation demasculinizes the reproductive system in rats. Journal of Urology 169 1582-1586. (doi:10.1097/01.ju. 0000046780.23389.e0)

Wong CH \& Cheng CY 2005 The blood-testis barrier: its biology, regulation and physiological role in spermatogenesis. Current Topics in Developmental Biology 71 263-296. (doi:10.1016/S0070-2153(05)71008-5)

Wong EW \& Cheng CY 2009 Polarity proteins and cell-cell interactions in the testis. International Review of Cell and Molecular Biology 278 309-353. (doi:10.1016/S1937-6448(09)-78007-4)
Wright SR, Boag AH, Valdimarsson G, Hipfner DR, Campling BG, Cole SP \& Deeley RG 1998 Immunohistochemical detection of multidrug resistance protein in human lung cancer and normal lung. Clinical Cancer Research 4 2279-2289.

Yakushiji K, Kai S, Yamauchi M, Kuwajima M, Osada Y \& Toshimori K 2006 Expression and distribution of OCTN2 in mouse epididymis and its association with obstructive azoospermia in juvenile visceral steatosis mice. International Journal of Urology 13 420-426. (doi:10.1111/j.1442-2042.2006. 01303.x)

Yu M, Zhang W, Qin L, Tian L \& Zhou C 2010 Enhancement of P-glycoprotein expression by hepatocyte transplantation in carbon tetrachloride-induced rat liver. Anatomical Record 293 1167-1174. (doi:10. 1002/ar.21160)

Zhang J, Gui Y, Yuan T, Bian C \& Guo L 2009 Expression of GAT1 in male reproductive system and its effects on reproduction in mice. Systems Biology in Reproductive Medicine 55 175-180. (doi:10.3109/19396360903030500)

Zwart R, Verhaagh S, Buitelaar M, Popp-Snijders C \& Barlow DP 2001 Impaired activity of the extraneuronal monoamine transporter system known as uptake-2 in Orct3/Slc22a3-deficient mice. Molecular and Cellular Biology 21 4188-4196. (doi:10.1128/MCB.21.13.4188-4196.2001)

Received in final form 22 November 2010 Accepted 6 December 2010 Made available online as an Accepted Preprint 6 December 2010 